NBER WORKING PAPER SERIES

FUNDING IN PUBLIC SECTOR PENSION PLANS - INTERNATIONAL EVIDENCE

\author{
Eduard Ponds \\ Clara Severinson \\ Juan Yermo \\ Working Paper 17082 \\ http://www.nber.org/papers/w17082
}

\author{
NATIONAL BUREAU OF ECONOMIC RESEARCH \\ 1050 Massachusetts Avenue \\ Cambridge, MA 02138
}

May 2011

The authors would like to thank Monika Bütler, Michael Orszag, Jeffrey Brown, participants of the NBER State and Local Pensions Conference on Aug.19-20, 2010 and Delegates to the OECD Working Party on Private Pensions for their helpful comments. They are also grateful to Yuecheng Liu for research assistance. The study has benefited from a research grant from Netspar. The views expressed are the sole responsibility of the authors and do not reflect those of their organisations, the National Bureau of Economic Research, or the governments of OECD Member countries. The authors are solely responsible for any errors.

NBER working papers are circulated for discussion and comment purposes. They have not been peerreviewed or been subject to the review by the NBER Board of Directors that accompanies official NBER publications.

(C) 2011 by Eduard Ponds, Clara Severinson, and Juan Yermo. All rights reserved. Short sections of text, not to exceed two paragraphs, may be quoted without explicit permission provided that full credit, including (O) notice, is given to the source. 
Funding in Public Sector Pension Plans - International Evidence

Eduard Ponds, Clara Severinson, and Juan Yermo

NBER Working Paper No. 17082

May 2011

JEL No. H55,H6,H7,H75,H83

\begin{abstract}
Most countries have separate pension plan for public sector employees. The future fiscal burden of these plans can be substantial as the government usually is the largest employer, pension promises in the public sector tend to be relatively generous, and future payments have to be paid out directly from government revenues (pay-as-you-go) or by funded plans (pension funds) which tend to be underfunded. The valuation and disclosure of these promises in some countries lacks transparency, which may be hiding potentially huge fiscal liabilities that are being passed on to future generations of workers.

In order to arrive at a fair comparison between countries regarding the fiscal burden of their DB public sector pension plans, this paper gathers more evidence on public sector pension plans regarding the type of pension promise and quantifies the future tax burden related to these pension promises. The reported liabilities are recalculated using both a fair value approach (local market discount rates) and a common, fixed discount rate across all countries which reflects projected growth in national income. We also estimate for a number of plans from a sample of OECD countries the size of the net unfunded liabilities in fair value terms as of the end of 2008. This fiscal burden can also be interpreted as the implicit pension debt in fair value terms.
\end{abstract}

Eduard Ponds

Tilburg University

Economics of Collective Pension Plans

The Netherlands

eduard.ponds@apg-am.nl

Clara Severinson

OECD Financial Affairs Division

2 Rue André Pascal

75016 Paris FRANCE

Clara.SEVERINSON@ oecd.org
Juan Yermo

OECD

Directorate For Financial and Enterprise Affaires

2, rue André Pascal

75016 Paris

Juan.YERMO@ oecd.org 


\title{
FUNDING IN PUBLIC SECTOR PENSION PLANS - INTERNATIONAL EVIDENCE
}

\author{
By Eduard Ponds, Clara Severinson and Juan Yermo ${ }^{1}$
}

\section{Section 1. Introduction}

In many countries the sustainability of fiscal policies is being questioned. A major driving force of this growing concern is age-related expenditure, such as health care and social security spending (public pensions). A sometimes overlooked reason for the sustainability problems, however, involves the pensions for government employees. In most countries there are separate pension plans for public sector employees. Traditionally, these specific arrangements are justified because they guarantee the security, integrity and independence of the employees and because they contribute to the attractiveness of a career in the civil service $^{2}$. General findings from research indicate that compared to pensions in the private sector, public sector pensions tend to offer more generous terms and feature lower funding levels (Palacios and Whitehouse 2006).

Reforms have been undertaken in many countries. These reforms have been oriented at bringing remuneration practices in the public sector more in line with those found in the private sector. Such reforms have generally involved lowering the generosity of public-sector pension schemes (e.g. Finland, France, Germany, Italy, Portugal, and Sweden). In some countries public sector workers have been transferred to the main public pension system (e.g. Austria, Chile, Czech Republic, Greece, Hungary, Mexico, Poland, Spain, and the United States), which in some cases include a fully-funded, defined contribution component (e.g. Chile, Denmark, Hungary, Mexico, and Poland). ${ }^{3}$

In addition, initiatives have been taken in a number of countries to introduce some degree of prefunding of public sector pensions via the establishment of reserve funds (e.g. Australia, Belgium, Finland, Germany, Ireland, and Sweden). Sometimes, however, fiscal pressures have overwhelmed the drive to prefunding as in 2003 when the Belgian government transferred the assets and liabilities of

${ }^{1}$ The authors of this paper are Mr. Eduard Ponds of Netspar and Clara Severinson and Juan Yermo of the OECD. The authors would like to thank Monika Bütler, Michael Orszag, Jeffrey Brown, participants of the NBER State and Local Pensions Conference on Aug.19-20, 2010 and Delegates to the OECD Working Party on Private Pensions for their helpful comments. They are also grateful to Yuecheng Liu for research assistance. The study has benefited from a research grant from Netspar. The views expressed are the sole responsibility of the authors and do not reflect those of their organisations or the governments of OECD Member countries. The authors are solely responsible for any errors.

${ }^{2}$ Pensions are an important component of total remuneration. Pensions may therefore help to explain that generally spoken gross wage pay in public sector is lower than in the market as the higher pension entitlements in the public sector compensate for gross wages differences (Disney et al. 2009).

${ }^{3}$ There have been some important pension policy reversals in recent years. At the end of 2010, the Hungarian government decided to stop contributions to the mandatory funded pillar for 14 months and to introduce coercive measures to switch people back into the public, PAYG system. At the beginning of 2011, the Polish government announced that it would reduce the mandatory contribution rate to the funded pillar from 7.3 percent to 2.3 percent of salaries. 
Belgacom, the former state-owned telephone monopoly, to the state system. The Portuguese government recently announced a similar planned assumption of the assets and liabilities of Portugal Telecom. Such moves, though worrisome if they lead to a depletion of the pension reserves, have also been justified as a way to unify pension arrangements between public and private sector workers.

Pre-funding implies that, in principle, the costs of pension promises are borne when those pension promises are accrued. In some countries, public sector DB schemes are pre-funded, but in other countries, public sector DB schemes are financed on a pay-as-you-go basis or deeply underfunded. On the liability side, sometimes benefits are not provisioned for at all in the public sector balance sheets. Those benefits that are accounted for in public sector balance sheets are not necessarily comparable to those provisioned for in the private sector as the assumptions employed may not use market-level discount rates, comparable longevity estimates or do not take into account the effect of future salary increases on benefits that have already been accrued. On the asset side, contribution levels are not necessarily sufficient. Finally, underfunding may persist for a long time in view of lax solvency regulations.

The funding practice of public sector plans has received increased attention in the United States, where US state governments offer their employees defined benefit pension plans. These pensions are generally pre-funded to a high extent. A recent study (Novy-Marx and Rauh 2009), however, reports that the market-valued underfunding of the pension liabilities of the state pension funds amounts on average to $24 \%$ of gross state product at the end of 2008. While these numbers have been disputed (see e.g. Angelo et al. 2010 and Lav and McNichol 2011), they reflect a high level of concern regarding the growing cost of public sector pension liabilities.

This study provides a survey of public sector pension plans outside the United States. In particular we are interested in public sector pension funds and their funding status. The calculations show that public sector funded DB plans outside the United States also tend to be underfunded.

The paper is structured as follows. Section 2 provides an overview of public sector pension plans in OECD countries. Section 3 examines specific public sector pension schemes in detail, describing the plan rules and financing mechanisms.

In Section 4 which deals with the funding position of public sector pension funds, the valuation method for liabilities is a key issue for this topic. We compare the funding positions of different plans as disclosed by the plan sponsors, as well as based on market discount rates in each country and using a common fixed discount rate. The plans generally tend to be underfunded. In order to put the underfunding in perspective, we compare in sections 5 and 6 the size of underfunding with the present value of future payments of unfunded plans.

The study stays away from the debate on whether and to what extent pension plans for public sector workers should be funded. Prefunding can be justified on various grounds. Firstly, it facilitates intergenerational tax smoothing (see e.g. D'Arcy et al. 1999), ensuring that each generation pays a more or less constant percentage of taxable income. Secondly, it can reap the benefits of diversification of pension fund investment, in particular into foreign markets. Thirdly, it can protect beneficiaries from the possibility of bankruptcy of the sponsoring governmental entity.

At the same time, there are various possible justifications for underfunding such public pension commitments. First, to the extent that funding risks can be smoothed over time as they can be shared with future generations of tax payers, underfunding in market value terms may be an optimal strategy (see e.g. Cui et al. 2010 and Munnell et al. 2010). Secondly, a funding surplus might also mobilize pressure to increase benefits which in turn leads in the longer term to higher funding costs and so underfunding. So for taxpayers it is rational to aim at underfunding rather than full funding or overfunding. Moreover, a funding 
surplus will enforce contribution cuts and once contributions are reduced, it is difficult to get them increased. The accountability horizon of pension fund management and politicians is much shorter than the horizon over which pension promises have to be met by adequate funding. This horizon gap may lead to pressure to underestimate costs and risks and to overestimate the earning capacity of assets. Thirdly, to the extent that prefunding leads to investment in domestic government bonds, a circularity in government funding may be created, with little added value relative to a PAYG system.

Ultimately, therefore, there is no single answer on what the optimal level of funding should be for such special DB arrangements. Each plan should target a level of funding that is appropriate given its circumstances. One critical element of this evaluation is the relationship between the growth rates of pension costs and the contribution or tax base. A related question is how the pension cost should be divided between the government and employees. To the extent that the government is at least partly responsible for financing pension benefits, increases in life expectancy lead to a growing wealth transfer from private sector tax-payers towards public sector pensioners. The government's contribution rate to the special DB arrangements of public sector workers has to grow in line with life expectancy.

One key policy message from the study is that better disclosure and transparency is needed over the pension commitments made by governments to their employees, as currently, information on public sector arrangements is often partial or not readily available. A debate should also be opened on how to compare these commitments between governments, not only on a domestic level, but also on an international basis. This paper is a first step in providing internationally comparable data on such arrangements for a sample of OECD countries.

\section{Section 2. Experience with Pension Plans for Government Workers in OECD Countries}

Pension promises for government workers are a major policy challenge for four main reasons. Firstly, the state is often a country's largest employer and as such, has large pension commitments to its public sector employees. Secondly, public sector pension promises are often of a defined benefit nature and tend to be relatively generous compared to private sector arrangements. In some countries, although not all, generous pension promises appear to have been made to make up for relatively lower cash pay in the public sector as compared to the private sector. Thirdly, these pension promises are in some countries underfunded or not funded at all (that is, financed on a pay-as-you-go basis). Fourthly, there is as yet no internationally standardised method of reporting public sector pension liabilities in contrast to the significant disclosure requirements that exist for exchange-listed private-sector companies and that are quite standardised across many countries. Practice varies widely by country, as does the extent to which the liabilities associated with these promises are disclosed and valued. Such lack of transparency and valuation requirements that may not be sufficiently conservative could mean that huge fiscal liabilities are potentially hidden, to be passed on to future generations of workers. This section and the next section discuss in turn of each of these issues.

\subsection{Share of government workers in total labour force}

As can be seen in Figure 2.1, government workers make up a substantial section of the labour force of many OECD countries, with the OECD average at close to 15\% of the total. In Norway and Sweden, government employees account for nearly $30 \%$ of the labour force. In contrast, in Korea and Japan employees in the state sector account for about $5 \%$ of the total employees in each country.

If employees of state-owned enterprises are included, the level of labour force coverage increases by a few percentage points in most countries. Figure 2.1 also shows the relative stability in the level of employment in general government and public corporations as a percent of the labour force between 1995 and 2005. 
Figure 2.1 Employment in general government as a percentage of the labour force (1995 and 2005)

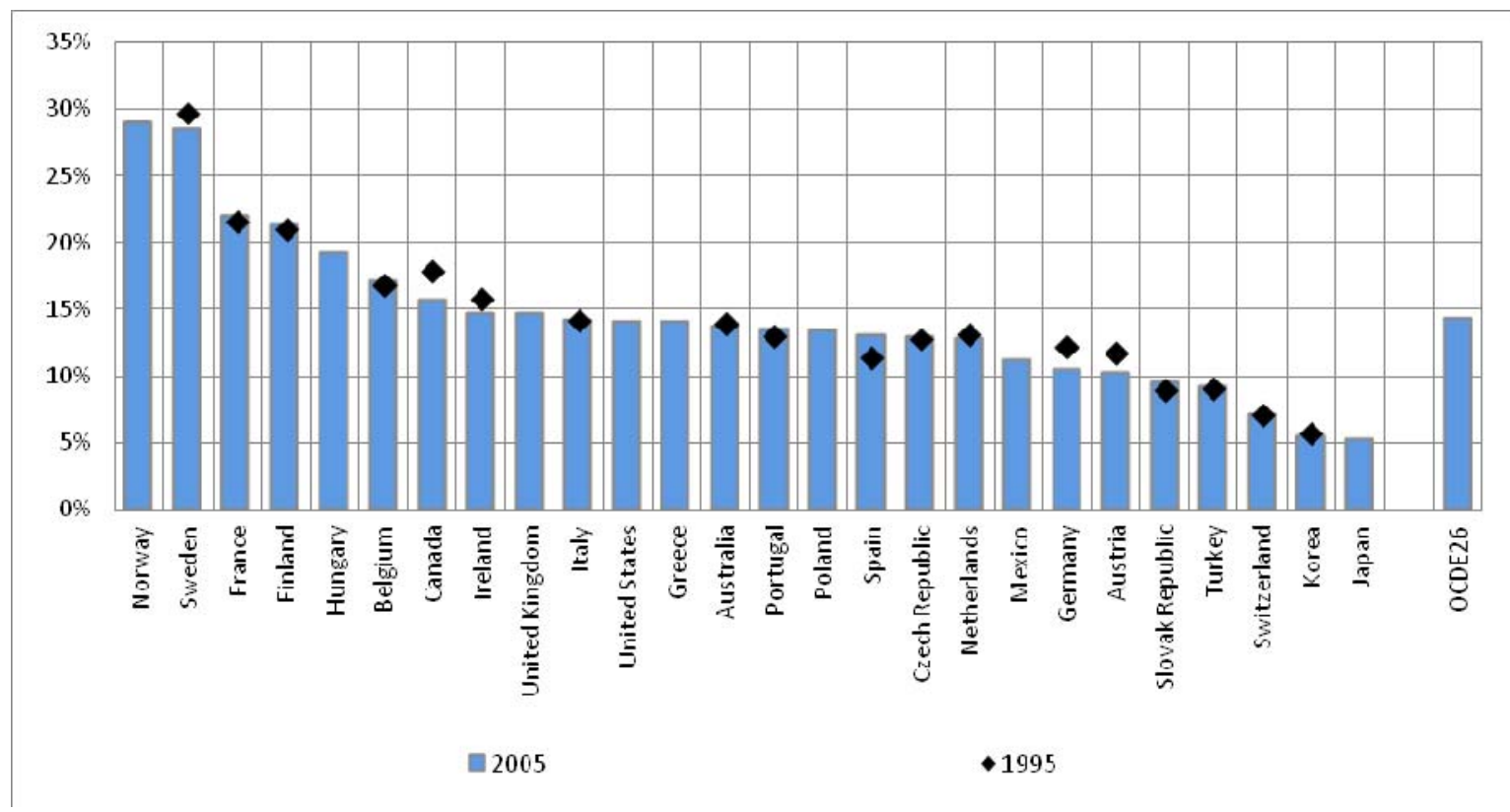

Source: Government at a Glance 2009

Data revised for Germany (2005 instead of 2004) - Governmental source

Greece: data refers to 2006 - Governmental Source - Staff under private law has been taken into account

Ireland: Governmental Source

Source of the data for UK: National Statistics Office (FTE)

Data for Slovak Republic: ILO and OECD

Last data available for Korea: 2004

Portugal: data refers to 1996 instead of 1995. Data in 1996 not including Madeira Autonomous Region in Subcentral Government 


\subsection{Types of pension plans for government workers in OECD countries}

Government workers' pension plans can be classified according to three key criteria. Financially speaking, the main distinction in the administration of government workers' pension arrangements is between funded and unfunded arrangements, but partially funded and book reserved arrangements should also be considered:

- Funded arrangements are those where an independent legal entity is established to hold pension plan assets on behalf of the plan members. Typically, assets would be held in a (legally separate) pension fund, although some countries allow public sector plan sponsors to purchase insurance to cover their pension obligations.

- Unfunded, or pay-as-you-go, arrangements are financed directly out of the government's coffers, though there may be reserves set up which are the legal property of the employer (government).

- Another category may be considered, book reserved arrangements, where the sponsoring government recognizes a liability (debt) on its balance sheet which reflects the accrued pensions of its members, but there are no legally separated pension assets.

- Some plans are partially funded, where the plan sponsor specifically targets a funding level that is less than $100 \%$. The remainder could be unfunded (pay-as-you-go) or it could be bookreserved.

A second classification is whether the pension plan is specific to government workers' or part of a broader arrangement, such as a national pension system. In the former case, it is also important to know whether the plan substitutes for or complements the nationwide pension system.

Finally, pension plans may be classified into defined benefit (DB), defined contribution (DC) and hybrid pension arrangements. DB plans provide benefits that are ultimately guaranteed by the state as sponsor. In DC plans, by contrast, the government's cost is limited to a prespecified contribution rate and hence do not create any future fiscal liabilities. ${ }^{4}$ In some countries, the DC plans can be considered "protected" (Pugh and Yermo 2008), where the pension entity or provider guarantees or targets a specific rate of return or benefit, but there is no automatic claim to the sponsoring employer in case of underfunding. In collective DC plans, risks are shared across the plan membership. Hybrid pension arrangements are those that offer a minimum return or benefit guarantee (e.g. cash balance plans) and may offer a variable (DC-like) benefit on top.

\section{Main features of pension arrangements for public sector workers in OECD countries}

Following Pinheiro (2004), Palacios and Whitehouse (2006) and further research, we describe in Table 2.1 the main features of pension arrangements for public sector workers in OECD countries. The table states whether such workers are covered by the main, national social security arrangement and whether they have a special arrangement (substitute or complementary to the general social security system). It also describes the main features of these special pension arrangements. In particular, it describes the financing mechanisms (funded with legal entities set up to hold the assets on behalf of

\footnotetext{
${ }^{4}$ Some DC systems, however, have DB elements and may involve contingent liabilities for governments if for
} example, the state provides or underwrites minimum return or pension guarantees. 
beneficiaries, unfunded schemes - though reserves may be built up - and book reserved plans) and the pension formula (DB or DC).

Table 2.1 Main features of pension arrangements for public sector workers in OECD countries

\begin{tabular}{|c|c|c|}
\hline Country & $\begin{array}{l}\text { Are public sector workers covered by the } \\
\text { general social security system? }\end{array}$ & $\begin{array}{l}\text { Is the substitute or complementary plan for } \\
\text { public sector workers DB or DC? Is it } \\
\text { funded, unfunded or book reserved? }\end{array}$ \\
\hline Australia & $\begin{array}{l}\text { No, they are excluded from the } \\
\text { mandatory DC system }\end{array}$ & $\begin{array}{l}\text { The Australian Public Sector } \\
\text { Superannnuation Scheme (PSS), a } \\
\text { partially funded (with assets at about } \\
30 \% \text { of liabilities), partially book- } \\
\text { reserved DB plan for employees of } \\
\text { the central government, was closed in } \\
2005 \text { and replaced with a DC plan } \\
\text { (PSSap) for new workers. Each State } \\
\text { has its own plan for its employees, } \\
\text { most of which are funded and based } \\
\text { on either DB or hybrid pension } \\
\text { formulas. }\end{array}$ \\
\hline Austria & Yes & DB, unfunded \\
\hline Belgium & No & DB, unfunded \\
\hline Canada & Yes & $\begin{array}{l}\text { There is a funded, DB pension plan } \\
\text { for federal government workers for } \\
\text { service after } 2000 \text { (book reserved } \\
\text { before then). Provincial governments } \\
\text { tend to offer specific, DB plans to } \\
\text { their personnel. These plans are } \\
\text { usually funded, though some are run } \\
\text { under the book reserve system. }\end{array}$ \\
\hline Chile & $\begin{array}{l}\text { Yes, except military personnel. The } \\
\text { mandatory pension system includes } \\
\text { a fully-funded DC pillar. }\end{array}$ & $\begin{array}{l}\text { There is no specific arrangement for } \\
\text { public sector workers, except military } \\
\text { personnel (unfunded, DB) }\end{array}$ \\
\hline Denmark & Yes & Collective DC, funded \\
\hline Finland & $\begin{array}{l}\text { No, but the rules are the same as for } \\
\text { private sector workers }\end{array}$ & $\begin{array}{l}\text { There is an unfunded DB pension } \\
\text { plan for central government workers } \\
\text { (VaEL). However, a buffer fund has } \\
\text { been established and the target } \\
\text { funding level is } 25 \% \text { of the VaEL } \\
\text { plan's liabilities. There is an } \\
\text { unfunded DB plan for local } \\
\text { government workers (KuEL). A fund } \\
\text { has been established to cover the } \\
\text { KuEL plan's annual costs on a short- } \\
\text { term basis. }\end{array}$ \\
\hline France & No & $\begin{array}{l}\text { DB, unfunded, plus a complementary } \\
\text { (voluntary) full-funded DC plan }\end{array}$ \\
\hline
\end{tabular}




\begin{tabular}{|c|c|c|}
\hline & & $\begin{array}{l}\text { (Prefon) and a complementary } \\
\text { funded DB scheme. }\end{array}$ \\
\hline Germany & $\begin{array}{l}\text { Employees are covered by the } \\
\text { general system and supplementary } \\
\text { pension arrangements. Civil } \\
\text { servants appointed for life are } \\
\text { covered by a special pension } \\
\text { system. }\end{array}$ & $\begin{array}{l}\text { All plans are DB arrangements. The } \\
\text { supplementary pension arrangements } \\
\text { are partially funded. For civil } \\
\text { servants appointed for life of almost } \\
\text { all federal states as well as at federal } \\
\text { level reserve funds have been set up. }\end{array}$ \\
\hline Greece & Yes & DB, unfunded \\
\hline Hungary & $\begin{array}{l}\text { Yes. The mandatory pension } \\
\text { system includes a fully-funded DC } \\
\text { pillar. }\end{array}$ & $\begin{array}{l}\text { There is no specific arrangement for } \\
\text { public sector workers. }\end{array}$ \\
\hline Iceland & Yes & Collective DC, funded \\
\hline Italy & Yes & $\begin{array}{l}\text { Some public sector employees (e.g. } \\
\text { teachers) have a complementary DC } \\
\text { plan. }\end{array}$ \\
\hline Korea & $\begin{array}{l}\text { No, there are separate arrangements } \\
\text { for public sector workers. }\end{array}$ & $\begin{array}{l}\text { The military, civil servants and } \\
\text { university and school teachers have } \\
\text { each their own unfunded, DB } \\
\text { arrangement. }\end{array}$ \\
\hline Japan & Yes & DB, unfunded \\
\hline Mexico & $\begin{array}{l}\text { Yes, for new public sector } \\
\text { employees since 2007. Mandatory } \\
\text { pension system includes a fully- } \\
\text { funded DC pillar. }\end{array}$ & $\begin{array}{l}\text { There is no specific arrangement for } \\
\text { new public sector workers since } \\
\text { 2007. Older workers are covered by } \\
\text { an unfunded, DB plan. }\end{array}$ \\
\hline Netherlands & Yes & $\begin{array}{l}\text { There is a funded DB pension plan } \\
\text { for government workers at all levels } \\
\text { and education (ABP) and a funded } \\
\text { DB plan for health care sector } \\
\text { (PfZW). }\end{array}$ \\
\hline Norway & Yes & $\begin{array}{l}\text { DB, funded arrangements for local } \\
\text { government workers. DB, partially } \\
\text { funded, partially book-reserved } \\
\text { arrangement for federal government } \\
\text { workers. }\end{array}$ \\
\hline Poland & $\begin{array}{l}\text { Yes. The mandatory pension } \\
\text { system includes a fully-funded DC } \\
\text { pillar. }\end{array}$ & $\begin{array}{l}\text { There is no specific arrangement for } \\
\text { public sector workers. }\end{array}$ \\
\hline Spain & Yes & $\begin{array}{l}\text { Central government workers have } \\
\text { both an unfunded DB and a funded, } \\
\text { DC plan. Some regional governments } \\
\text { (e.g. Basque Country and Catalonia) } \\
\text { sponsor funded DB plans for their }\end{array}$ \\
\hline
\end{tabular}




\begin{tabular}{|c|c|c|}
\hline & & personnel \\
\hline $\begin{array}{l}\text { Slovak } \\
\text { Republic }\end{array}$ & Yes & $\begin{array}{l}\text { There is no specific arrangement for } \\
\text { public sector workers. }\end{array}$ \\
\hline Sweden & Yes & $\begin{array}{l}\text { Arrangements for local and federal } \\
\text { employees include both DB and DC } \\
\text { elements. Arrangements are funded } \\
\text { for federal government workers. For } \\
\text { local government workers } \\
\text { arrangements are partially funded or } \\
\text { book-reserved and partially pay-as- } \\
\text { you-go. (For local-government } \\
\text { workers, pre-1997 obligations are } \\
\text { pay-as-you go, whereas post-1997 } \\
\text { obligations are funded or book- } \\
\text { reserved.) }\end{array}$ \\
\hline Switzerland & Yes & $\begin{array}{l}\text { DB, funded arrangements for centra } \\
\text { and local government workers. }\end{array}$ \\
\hline Turkey & $\begin{array}{l}\text { Yes, except military personnel, coal } \\
\text { miners and school teachers. }\end{array}$ & $\begin{array}{l}\text { There is no specific arrangement for } \\
\text { public sector workers, except military } \\
\text { personnel who are covered by a DB, } \\
\text { funded plan (Oyak). Coal miners and } \\
\text { primary school teachers also have } \\
\text { their own DB plan. }\end{array}$ \\
\hline $\begin{array}{l}\text { United } \\
\text { Kingdom }\end{array}$ & $\begin{array}{l}\text { Yes, although some are contracted } \\
\text { out of the state pension system. }\end{array}$ & $\begin{array}{l}\text { There is a book-reserved, DB plan } \\
\text { for civil servants of the centra } \\
\text { government and funded, DB plans for } \\
\text { employees of local authorities. There } \\
\text { are also separate book-reserved DB } \\
\text { plans for employees of the National } \\
\text { Health Service, for teachers, fire } \\
\text { department, armed forces and police. }\end{array}$ \\
\hline United States & $\begin{array}{l}\text { Yes, for most states and central } \\
\text { government workers hired after } \\
1983 \text {. Some states maintain } \\
\text { arrangements that substitute for } \\
\text { social security. }\end{array}$ & $\begin{array}{l}\text { New U.S. federal civilian employees, } \\
\text { first hired after 1983, are } \\
\text { automatically covered by FERS, a } \\
\text { three tiered system that consists of } \\
\text { social security, a specific, unfunded } \\
\text { DB plan and the Thrift Savings Plan } \\
\text { which is a funded, DC plan. States } \\
\text { and local governments offer mainly } \\
\text { DB plans, which are often funded. }\end{array}$ \\
\hline
\end{tabular}

Most OECD governments, with few exceptions, offer special DB arrangements for public sector workers, which in most instances are complementary to the general social security system. These special DB plans create a pension liability for governments beyond that already reported in social security arrangements. Table 2.1 also shows that at the federal level, unfunded (pay-as-you-go) schemes are the most common, followed closely by the number of funded schemes. At the local government level, funded 
schemes are more popular than unfunded (pay-as-you-go schemes). Some schemes at the federal and local government level are book-reserved, whereas a small number of schemes target partial funding.

Table 2.1 also reveals some countries where government workers have been fully or largely integrated into both the PAYG and the funded part of the mandatory pension system. Such countries include Chile, Denmark, Hungary, Iceland, Mexico, Poland and the Slovak Republic. With the exception of Denmark and Iceland, these are all countries that reformed their public pension system structurally, replacing part of the public pension with "carve-out" individual accounts. ${ }^{5}$ Chile led such reform in 1981, including public sector workers in the new system (except the military, who maintained a special DB system financed directly from the government's budget). The inclusion of government workers in the mandatory private pension system in Denmark and Iceland can be traced back to a long history of collective bargaining at the industry level. The mandatory private pension system in Iceland dates from 1974.

\subsection{Pension expenditure and pension liabilities}

Information regarding public expenditure on government workers' pensions is readily available for most OECD countries. However, international comparability is problematic because of the way the information is reported. The OECD's SOCX database, for example, reports pensions paid to former civil servants through autonomous funds as a private spending item (Australia (partially), Canada, Denmark, the Netherlands, Sweden and the United Kingdom). All social benefits not provided by general government are considered 'private'. ${ }^{6}$

A recent study by Müller et al. (2009) has collected information for selected European countries. In France and Germany, spending on pensions for public sector workers accounts for $17 \%$ of total public spending on pensions while in Austria it is $27 \%$. The highest ratio of government workers' pension expenditure to GDP is also found in these countries, as plans provide benefits that replace those of the standard social security system.

\footnotetext{
${ }^{5}$ In all these cases, at least part of the social security contribution was transferred to the new fully-funded, DC system.

${ }^{6}$ This is in line with SNA (1993), para 8.63 states: “... Social insurance schemes organized by government units for their own employees, as opposed to the working population at large, are classified as private funded schemes or unfunded schemes as appropriate and are not classified as social security schemes. ...” In practical terms, for pension payments to former civil servants to be classified as private, these payments have to go through autonomous private funds (e.g. separate pension and/or insurance companies), for which the government does not make up the deficit on a regular basis (e.g. in practice benefit schemes which are defined contribution plans). Non-autonomous pension schemes (including pension benefits paid directly from the government budget) remain institutionally in the government sector.
} 


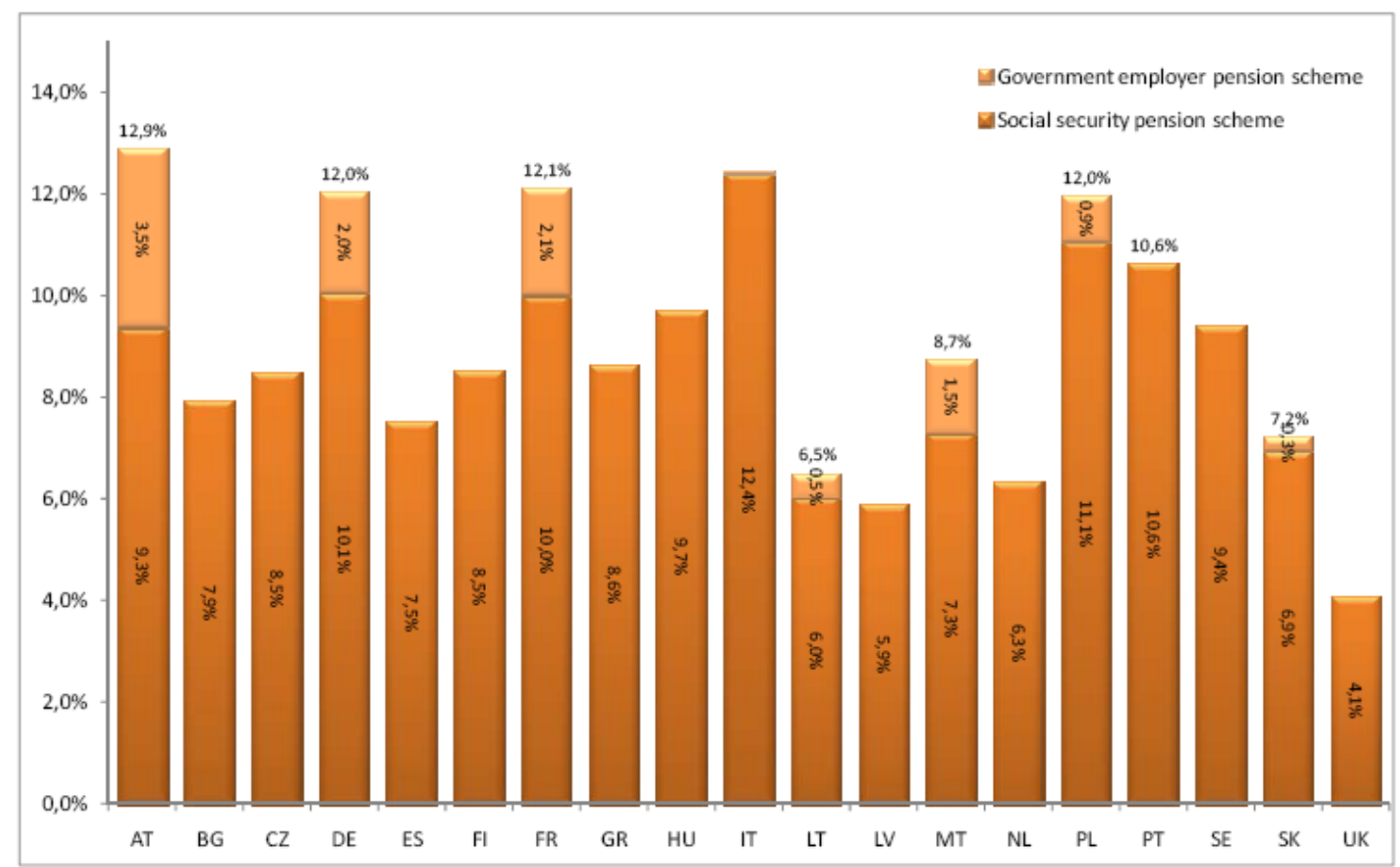

Source: Müller et al. (2009)

Unlike that for private sector pension schemes (if sponsored by publicly-traded corporations), the reporting of government workers' pension liabilities is not yet standardized internationally, although there is an ongoing initiative to do so by the OECD and the IMF via the so-called system on national accounts (SNA). Some countries, like Australia and Canada, already require their governments (at all levels) to report their pension liabilities for their employees as a liability on the government's balance sheet (if there are no associated plan assets, then these pension arrangements would in effect be transformed into book reserves). By making these debts explicit, these governments would formally quantify and acknowledge the future commitments that they are responsible for.

Some of the more contentious issues regarding the valuation of public sector liabilities are the extent to which benefits should incorporate future salary growth and the discount rate to be used. In the private sector, such issues have been largely solved through the application of the International Accounting Standard Board's IAS19 standard for pension benefits in the EU and other countries, and similar standards applied in Japan and the United States. The choice of discount rate for calculating public sector liabilities is a particular controversial topic because of the huge impact small changes in discount rates can have on the size of the liability.

Much of the recent financial economics literature proposes that public pension should be computed using some reasonable government paper rate. However, there is an ongoing debate regarding the application of market-based discount rates, given that pensions are long-term liabilities, that there is no market for such liabilities and that there is no a priori expectation that such liabilities will be sold by governments or otherwise transferred to an insurance companies. Hence, to the extent that a government bond yield is to be used to calculate public pension liabilities it may be preferable to use a long-term average measure or an expectation of its future value, based on long-term trends in economic growth and 
inflation. Actuaries have also traditionally adjusted such discount rates upwards to reflect the higher longterm return that may be expected from pension fund investments in equity and other instruments.

The next section of this paper examines some specific public sector pension plans in several countries in an attempt to highlight in more detail some of the broad concerns identified above.

\section{Section 3. Examination of Individual DB Public Sector Pension Plans}

\subsection{Introduction}

The prior section of this paper highlighted some high-level policy challenges that are facing public sector pension schemes, namely the large size of the government as an employer in most countries, the relative generosity of pension promises in public sector schemes relative to private sector schemes, and the funding and disclosure of public sector pension obligations.

This section looks in detail at specific pension schemes for public sector workers in a number of countries in order to identify how the broad-level issues discussed above impact individual schemes. Table 3.1 lists the plans that have been examined in detail. The plans were selected on the basis of availability of data and are not necessarily representative of the universe of public sector plans in the country. However, for a few countries, the pension plans selected cover a large section of the public sector workforce and may therefore be considered representative of the average public sector employee.

Data on all these plans has been obtained from public sources, mainly web-sites, annual reports (either 2008 or 2009 depending on availability) and official statistics. We primarily selected OECD countries where there are special DB arrangements for public sector workers, both funded and unfunded.

Some countries such as Australia, Canada and the United Kingdom are characterised by a large number of individual schemes from various employers in the public sector, whereas other countries such as the Netherlands, the Nordic countries and France are characterised by large and harmonised centrally administered schemes. In most of the countries we examined, countries have pension schemes for their federal employees that are separate and distinct from the pension schemes of other public sector employees, although in the Netherlands this is not the case.

This report examines only a few public sector pension plans in each country. In the countries with the large centralised public schemes (for example, the Netherlands, the Nordic countries and France), this means that a large portion of the public sector has been covered. In the countries with many individual plans (such as Australia, Canada and the United Kingdom), the report covers a smaller portion of the public sector. Figure 3.1 below shows the portion of the public sector covered by the individual pension schemes examined. This has been measured as the total number of active members in the individual pension schemes examined in each country over the total number of each respective country's public sector employees. 


\section{DAF/AS/PEN/WD(2010)9/REV1}

The pension schemes examined in detail in this report are shown below; the examined schemes covering federal pensions have been highlighted in the chart. (The pension schemes covering federal employees are the dark-shaded schemes.)

Table 3.1: Plans under consideration

\begin{tabular}{|c|c|c|c|c|c|c|c|c|c|c|}
\hline & Australia & Canada & Finland & France & Germany & $\begin{array}{c}\text { Hong Kong, } \\
\text { China } \\
\end{array}$ & Netherlands & Norway & Sweden & UK \\
\hline $\begin{array}{c}\text { Number of plans } \\
\text { examined }\end{array}$ & 5 & 2 & 2 & 3 & 1 & 3 & 2 & 3 & 2 & 7 \\
\hline - & \begin{tabular}{|c|} 
Australia - Public \\
Sector \\
Superannuation \\
Scheme (PSS) - for \\
federal employees \\
\end{tabular} & $\begin{array}{l}\text { Canada - Pension } \\
\text { Plan for the Public } \\
\text { Service of Canada }\end{array}$ & $\begin{array}{l}\text { Finland VaEL I } \\
\text { StaPL (federal } \\
\text { employees) }\end{array}$ & \begin{tabular}{|c|} 
France - Le Regime \\
des fonctionnaires \\
de l'Etat, de \\
magistrats et des \\
militaires Notes \\
\end{tabular} & $\begin{array}{l}\text { Germany Civil } \\
\text { Servants Pension } \\
\text { Plan }\end{array}$ & $\begin{array}{c}\text { Hong Kong (China) } \\
\text { Civil Service } \\
\text { Provident Fund } \\
\text { Scheme (a DC } \\
\text { scheme) } \\
\end{array}$ & Netherlands ABP & $\begin{array}{l}\text { Norway - SPK - for } \\
\text { federal employees }\end{array}$ & $\begin{array}{c}\text { Sweden - SPV } \\
\text { (federal employees) }\end{array}$ & $\begin{array}{l}\text { UK Principle Civil } \\
\text { Service Pension } \\
\text { Scheme ("Nuvos") }\end{array}$ \\
\hline 2 & \begin{tabular}{|c|} 
Australia - Public \\
Sector \\
Superannuation \\
Accumulation Plan \\
(PSSAP) - for \\
federal employees (a \\
DC scheme) \\
\end{tabular} & Canada OTP & $\begin{array}{c}\text { Finland KuEL / } \\
\text { KompPL (local govt } \\
\text { employees) }\end{array}$ & $\begin{array}{c}\text { France - CNRACL } \\
\text { Caisse nationale de } \\
\text { retraites des agents } \\
\text { des collectivités } \\
\text { locales }\end{array}$ & & $\begin{array}{l}\text { Hong Kong (China) } \\
\text { New Pension } \\
\text { Scheme }\end{array}$ & Netherlands PfZW & \begin{tabular}{|c|} 
Norway - Public \\
Sector \\
Pensjonskasser - for \\
local govt ee's
\end{tabular} & $\begin{array}{l}\text { Sweden - local } \\
\text { government } \\
\text { employees }\end{array}$ & UK NHS \\
\hline 3 & \begin{tabular}{|c|} 
Australia - The \\
Commonwealth \\
Superannuation \\
Scheme (CSS) - for \\
federal employees
\end{tabular} & & & $\begin{array}{c}\text { France - Retraite } \\
\text { Additionelle de la } \\
\text { Fonction Publique }\end{array}$ & & $\begin{array}{l}\text { Hong Kong (China) } \\
\text { Old Pension } \\
\text { Scheme }\end{array}$ & & $\begin{array}{l}\text { Norway - KLP - for } \\
\text { local govt ee's }\end{array}$ & & $\begin{array}{l}\text { UK Teachers' } \\
\text { Pension }\end{array}$ \\
\hline 4 & \begin{tabular}{|c|} 
Australia - State \\
Super SAS Trustee \\
Corporation
\end{tabular} & & & & & & & & & $\begin{array}{c}\text { UK Local } \\
\text { Government } \\
\text { Merseyside pension } \\
\text { fund (1 of 99) }\end{array}$ \\
\hline 5 & $\begin{array}{l}\text { Australia - } \\
\text { ESSSuper }\end{array}$ & & & & & & & & & $\begin{array}{c}\text { UK Local } \\
\text { Government West } \\
\begin{array}{c}\text { Yorkshire pension } \\
\text { fund (1 of 99) }\end{array} \\
\end{array}$ \\
\hline 6 & & & & & & & & & & \begin{tabular}{|c|} 
UK Local \\
Government Greater \\
Manchester pension \\
fund (1 of 99)
\end{tabular} \\
\hline 7 & & & & & & & & & & \begin{tabular}{|c|} 
UK Local \\
Government West \\
Midlands pension \\
fund (1 of 99) \\
\end{tabular} \\
\hline
\end{tabular}


Figure 3.1: Size of examined pension plans

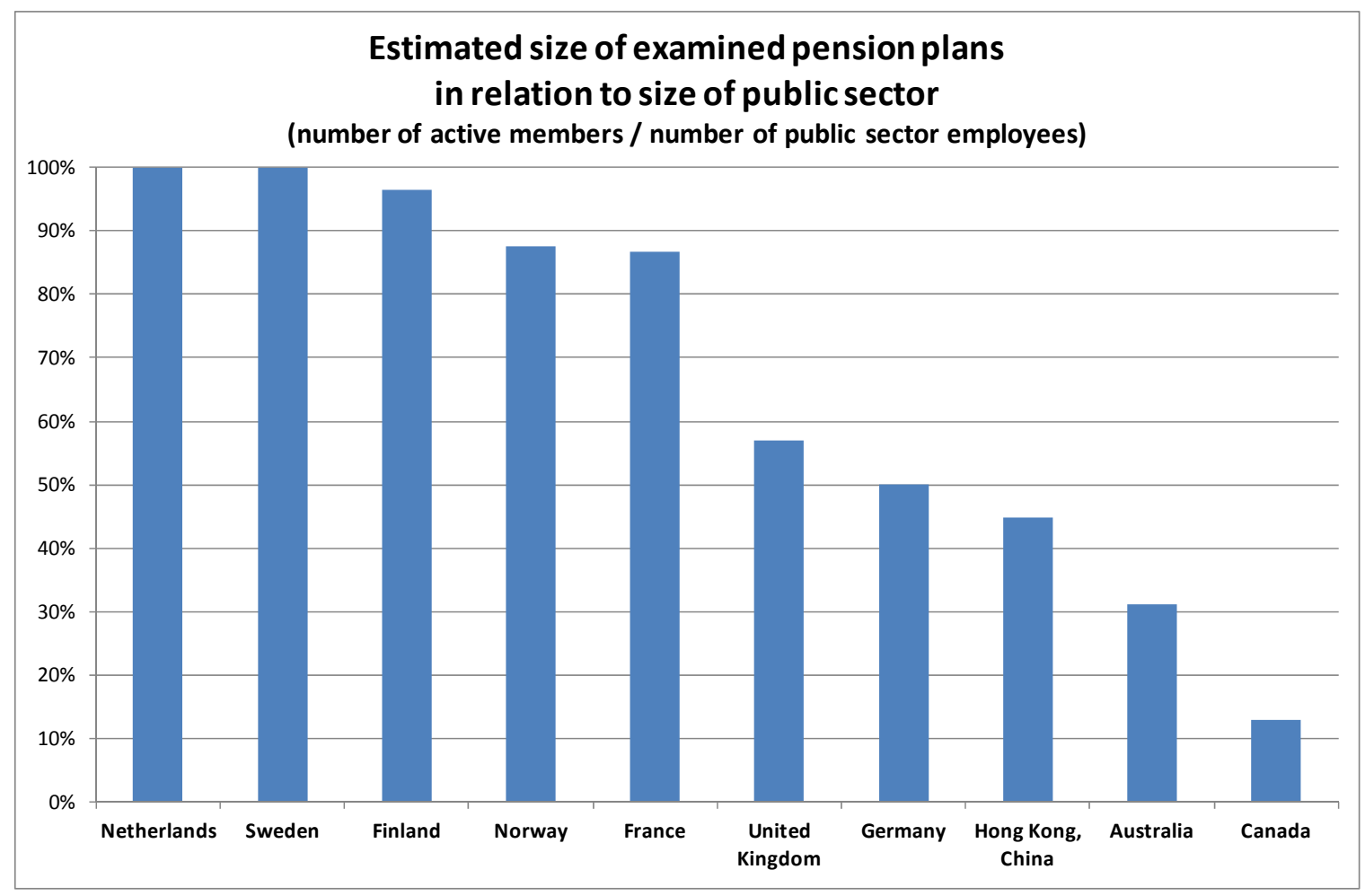

The total number of active members varies greatly for the plans examined. The greatest number of actives employees is in the French schemes examined at approximately 4.4 million members. The smallest number of active members is in the Hong Kong, China schemes examined with approximately 157,000 active members. The total approximate active membership of the schemes examined, grouped by country, is shown below: 
Figure 3.2: Active members in examined pension plans

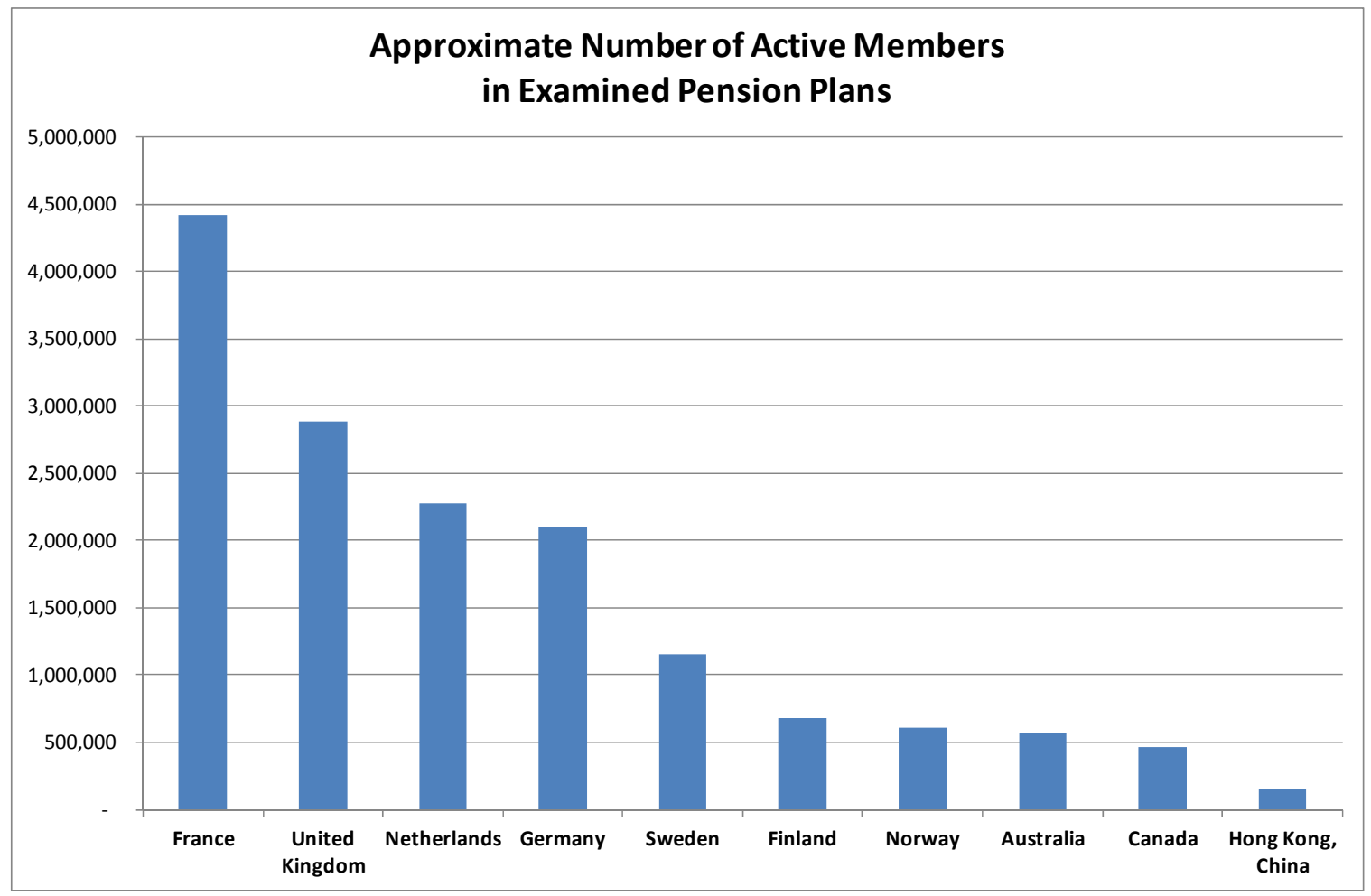

\subsection{What is the Pension Promise?}

One of the policy challenges faced by public sector pension schemes is that they tend to offer relatively generous DB pension promises, when compared to private sector arrangements. These higher pension promises appear to have been made in a number of cases to make up for lower cash pay in the public sector, relative to the private sector.

The first question is what types of benefits are offered by the individual pension plans that have been examined. The individual pension schemes that we examined are mainly DB. The plans in France, Germany and Norway are final pay DB schemes. Canada's OTP plan is final average pay, whereas Canada's plan for federal government workers is a highest average pay scheme. The schemes examined in Finland and the Netherlands are career average schemes. The UK scheme for civil servants is career average, whereas the other examined UK schemes are final average pay schemes, although the government is considering replacing them by career-average plans. ${ }^{7}$ The plans examined in Australia, and Sweden are a combination of DB and DC. There are three Hong Kong, China scheme for federal employees: Those members that joined after 1 June 2000 are covered by a DC scheme, whereas members who joined before then are covered by highest pay DB schemes.

Members of the French pension schemes for public sector employees are not eligible for the state social security pension scheme, so the public sector pension scheme must therefore cover any resulting shortfall. Most German civil servants are also covered by schemes that replace the general social

${ }^{7}$ The Interim Hutton report published in October 2010 recommended also later retirement ages and an increase in employee contributions in all but the armed forces pension plan. 
security system. The pension schemes examined in Canada, Finland, and Norway are integrated with the state social security pension scheme. The pension schemes examined in Hong Kong, China, the Netherlands, Sweden and the United Kingdom are distinct and complementary to the state social security pension scheme, although in the United Kingdom, some public sector pension schemes are contracted out of the state pension system and must make up the benefit shortfall.

The second question is how do the individual schemes examined compare to pension schemes offered in the private sector in the various countries. In Australia, Canada, France, Germany, Hong Kong - China, Netherlands, and the United Kingdom, the schemes examined offer more generous pension benefits than what is typical practice in the private sector. In Finland, the schemes give similar benefits to those found in the private sector. In Norway, the level of benefits is similar to that typically offered by large and mid-size employers. Small Norwegian employers, however, tend to offer significantly less generous DC schemes due to the government-mandated minimum pension level that was introduced in 2006. In Sweden, the schemes examined give slightly less generous DB benefits than the scheme that covers most private white-collar workers; although the public sector schemes are more generous than the DC scheme offered to most private sector blue collar workers and younger white collar workers who also receive DC benefits.

The question as to how the relatively more generous level of benefits in the public sector is offset by lower levels of cash compensation has not been explored in this paper, but could be the subject of further research (compare Disney et al. 2010 for a recent study for the UK).

\subsection{Disclosure and Financing}

Most of the plans examined appear to have disclosed their full liabilities, either in the financial statements of the employer or the state (for the plans covering federal employees). Full disclosure seems to be provided for by the pension schemes examined in Australia, Canada, the Netherlands, Norway and the United Kingdom as does the complementary pension scheme for public sector workers in France and the Swedish plan for federal employees.

Full disclosure of liabilities is typically practiced by plans that are book-reserved or funded. For the plans examined in this paper this has been the case: full liabilities appear to have been disclosed for the plans financed by book-reserving or funding, whereas the pay-as-you-go plans have had no disclosure of liabilities. The one exception is the Swedish local government plans which practices partial funding/book-reserving and partial pay-as-you-go funding. The portion of the liabilities for these plans that is funded or book-reserved is disclosed on a net of assets basis only.

The following chart shows the financing method used by each of the examined plans: 
Table 3.2: Financing method of examined plans

\begin{tabular}{|c|c|c|c|c|c|}
\hline & Funded & Book-reserved & $\begin{array}{l}\text { Partly Funded I } \\
\text { Partly Book- } \\
\text { reserved }\end{array}$ & $\begin{array}{l}\text { Partly Funded I } \\
\text { Partly Pay-as- } \\
\text { you-Go } \\
\end{array}$ & Pay-as-you-Go \\
\hline \multirow{4}{*}{ Australia } & & & $\begin{array}{l}\text { Australia PSS (federal } \\
\text { ee's) }\end{array}$ & & \\
\hline & Australia CSS (federal ee's) & & & & \\
\hline & $\begin{array}{l}\text { Australia StateSuper SAS } \\
\text { Trustee Corporation (pooled } \\
\text { fund covers four closed } \\
\text { NSW public sector } \\
\text { superannuation schemes) }\end{array}$ & & & & \\
\hline & $\begin{array}{l}\text { Australia ESSSuper } \\
\text { (emergency services ee's } \\
\text { and state ee's of Victoria) }\end{array}$ & & & & \\
\hline Canada & $\begin{array}{l}\text { Canada: Pension Plan for } \\
\text { the Public Service of } \\
\text { Canada } \\
\text { Canada OTP }\end{array}$ & & & & \\
\hline \multirow{2}{*}{ Finland } & & & & $\begin{array}{l}\text { Finland VaEL (federal } \\
\text { ee's) }\end{array}$ & \\
\hline & & & & $\begin{array}{l}\text { Finland KuEL (local } \\
\text { govt ee's) }\end{array}$ & \\
\hline France & $\begin{array}{l}\text { France - Retraite } \\
\text { Additionelle de la Fonction } \\
\text { Publique (Complementary } \\
\text { pensionn scheme for federal } \\
\text { ee's, local govt ee's and } \\
\text { hospitals) }\end{array}$ & & & & $\begin{array}{l}\text { Pension scheme for } \\
\text { federal ee's, } \\
\text { magistrates and } \\
\text { military } \\
\text { CNRACL (local govt } \\
\text { ee's) }\end{array}$ \\
\hline \multirow[b]{2}{*}{ Hong Kong } & & & & & $\begin{array}{l}\text { Hong Kong (China) } \\
\text { New Pension Scheme }\end{array}$ \\
\hline & & & & & $\begin{array}{l}\text { Hong Kong (China) } \\
\text { Old Pension Scheme }\end{array}$ \\
\hline Germany & & & & & $\begin{array}{l}\text { Germany Civil } \\
\text { Servants Pension Plan }\end{array}$ \\
\hline Netherlands & $\begin{array}{l}\text { ABP (all govt ee's and } \\
\text { education sector) }\end{array}$ & & & & \\
\hline & PfZW (health care sector) & & & & \\
\hline Norway & \begin{tabular}{|l|} 
Norway KLP (local govt \\
ee's) \\
Norway Pensionskasser for \\
local govt ee's)
\end{tabular} & & $\begin{array}{l}\text { Norway SPK (federal } \\
\text { ee's) }\end{array}$ & & \\
\hline Sweden & Sweden SPV (federal ee's) & & & $\begin{array}{l}\text { Sweden local govt } \\
\text { ee's }\end{array}$ & \\
\hline United Kingdom & $\begin{array}{l}\text { UK local govt Merseyside } \\
\text { pension fund } \\
\text { UK local govt west } \\
\text { Yorkshire pension fund } \\
\text { UK local govt Greater } \\
\text { Manchester pension fund } \\
\text { UK local govt West } \\
\text { Midlands pension fund }\end{array}$ & $\begin{array}{l}\text { UK Principle Civil } \\
\text { Service (new plan for } \\
\text { federal ee's) } \\
\text { UK NHS (hospital } \\
\text { ee's) } \\
\text { UK Teacher's Pension }\end{array}$ & & & \\
\hline
\end{tabular}


The total disclosed liabilities of the pension schemes examined in these countries, and in Finland and Sweden where partial disclosure is practiced, is shown in figure 3.3 below. It should be noted that these pension liabilities have been determined using the regulatory requirements in each respective country, and are therefore not directly comparable. Therefore, the chart below is only intended to give a very general and relative order of magnitude of the size of the liabilities for these schemes.

The main schemes for French public sector workers and the German plan for civil servants are financed on a pay-as-you-go basis and no liabilities are publicly disclosed.

In Sweden, the liabilities for the SPV plan for federal employees appear to be fully disclosed in the Swedish State's financial statements. ${ }^{8}$. For the plans covering Swedish local government employees, the story is a bit more complicated. Pension obligations that relate to pension promises accrued by employees after 1997 are accounted for on the balance sheet (either funded or bookreserved), unless they have been insured away. According to Statistics Sweden, pension obligations, net of assets, for the Swedish local government pension schemes amount to 60.6 BSEK as of 31 December 2009 (5.9 BEUR). However, the local governments can choose whether or not to disclose pension obligations related to pension promises accrued prior to 1997 and most local governments do not provision for these pre-1997 liabilities in their balance sheets. As of 31 December 2009, the value of undisclosed pension liabilities for the Swedish local governments amounted to 344.1 BSEK (33.6 BEUR). ${ }^{9}$

The Finnish plans, KuEL for local government employees and the VaEL for federal employees are partly financed on a pay-as-you-go basis. The KuEL plan for local government employees is financed on a pay-as-you-go basis, although a fund was set up in 1988 to cover annual costs on a short-term basis. The VaEL plan for federal employees established a buffer fund in 1990. Annual expenditures are paid for out of the national budget, and then $40 \%$ of those expenditures are reimbursed by the buffer fund. Assets will continue to be accumulated in the buffer fund until $25 \%$ of the total liabilities of the VaEL plan is pre-funded.

\footnotetext{
${ }^{8}$ The liabilities that are financed on a pay-as-you-go basis in the Swedish local government pension plan are not disclosed in the local government financial statements, but Statistics Sweden publishes the associated liability figure each year.

${ }^{9}$ Statistics Sweden, "Statement of accounts for the municipalities and county councils 2009. Preliminary data from profit/loss statements and balance sheets”, 26 April 2010.
} 
Figure 3.3: Disclosed liabilities of examined pension schemes (in billion euros)

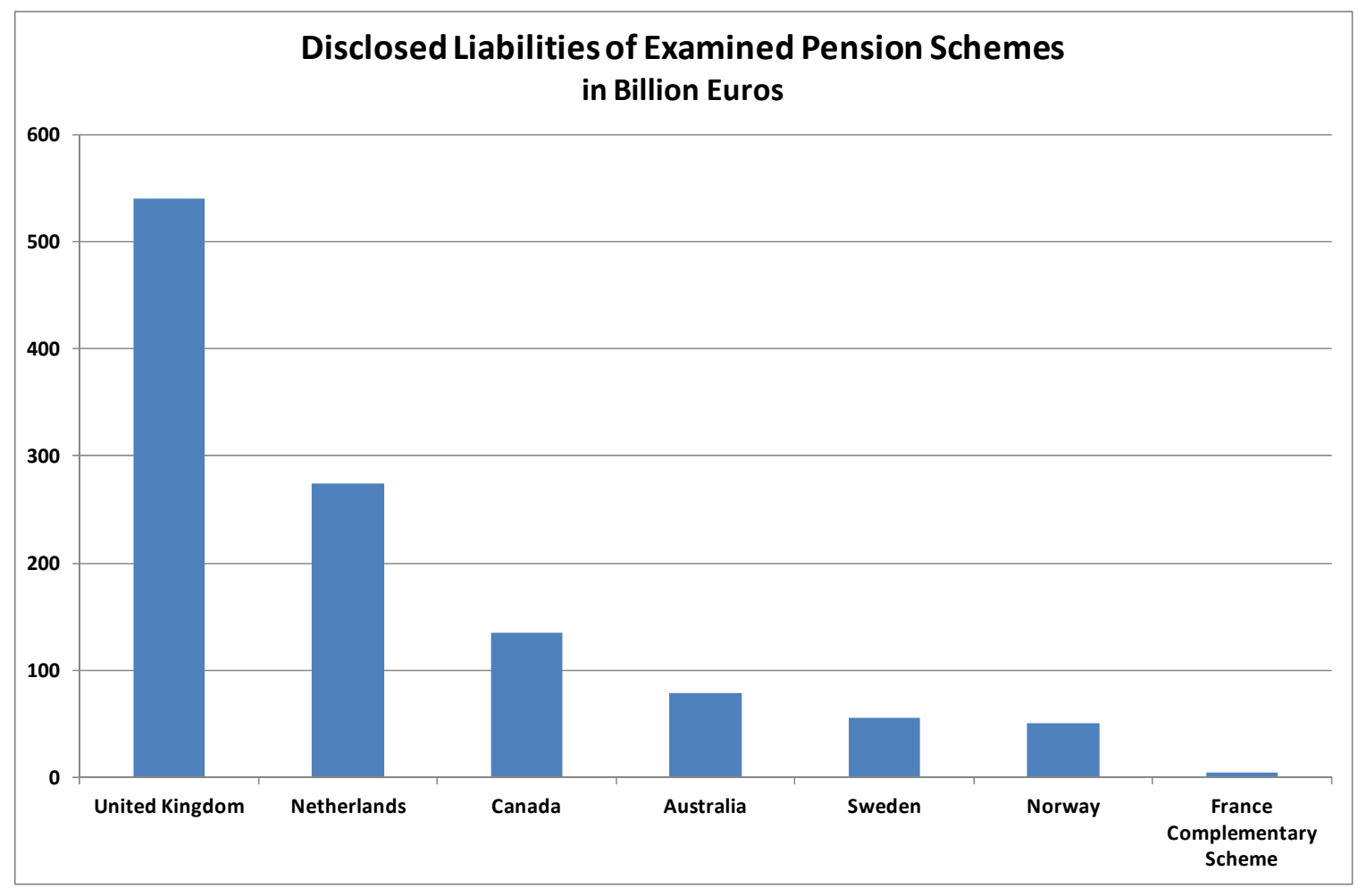




\section{Section 4. Funded public sector pension plans}

\subsection{Introduction}

This section presents evidence on financial aspects of a selection of funded defined benefit (DB) plans in the public sector for a number of countries. (The selected plans are the same as those examined in Section 3 of this paper, plus some new plans.) It is clear from the previous sections that dominant variety of financing approaches are used for pension arrangements in the government sector across countries. Discussion on plan reforms may stimulate the transition to funded plans in certain countries (compare for example Maurer et al. 2009 for Germany and for the United Kingdom the Public Sector Pensions Commission 2010).

This section starts with a comparison of a number of funded DB plans on three different bases. We find that funded plans generally tend to be underfunded and we discuss a number of arguments why this may be the case. To put underfunding in perspective, we compare the size of underfunding in funded plans with the financial obligations captured in unfunded plans of a number of countries.

\subsection{Funding and methods of valuation of liabilities}

Participants in a traditional DB plan typically accrue pension rights based on years of service, annual accrual rate and wage income over the career. The accrued rights give prospect on a stream of annual pension payments as of retirement age. These payments may be indexed for some reference variable, for example price inflation or wage growth. A pension fund accounts for the future pension payments by reporting the size of the pension liabilities. The liability of a pension plan essentially is the discounted value of this stream of future pension cash flows to the present.

There has been a debate on which method of discounting is appropriate in valuing pension liabilities (Exley et al. 1997, Bader and Gold 2003, Kortleve et al. 2006, Waring 2009). For a long time, liabilities were valued using a fixed discount rate which may reflect the expected return on assets, but since the nineties of the previous century the economic approach based on fair valuation principles and a market discount rate has increasingly substituted for the actuarial method. The private sector for the most part no longer utilizes the actuarial method for disclosure purposes as internationally recognized accounting standards prescribe that companies have to report their pension obligations in fair value terms based on economic principles.

For public sector pension plans, there is a large variety in discounting practice. Both the fixed discount rate method and the economic method are in use. The liabilities that the examined plans and the discount rates used and whether the discount rates are fixed or market-related are discussed in the following section.

\subsection{Reported evidence on funding positions}

Table 4.1 informs about the financial position of a number of funded pension plans from different countries as of end 2008 as reported by the plan sponsors of the schemes. All monetary terms are in Euros. Assets are reported at their disclosed value. The value of the liabilities is determined by the discounting method. The information about the discount method used in the table shows up a large variety as to this aspect.

The Netherlands has two public sector plans, APB for the sectors government and education, and PfZW for the health care sector. Like all other pension funds in the Netherlands, the public sector pension plans in the Netherlands have to report the fair value of their nominal liabilities. The nominal 
liabilities are the accrued pension rights without taking into account future indexation. The supervision prescribes that the discount rates for the various terms have to be derived from the nominal swap rates curve $^{10}$. End 2008 the swap rate corresponding with the duration of the liabilities for the two plans is $3.56 \%$.

The United States is present in the table with the aggregate information on the value of assets and liabilities of all public sector plans (derived from Novy-Marx and Rauh 2009). The plans in the United States use the actuarial method as prescribed by the Government Accounting Standards Bounds (GASB). GASB 25 states that the discount rate should be based on "an estimated long-term yield for the plan, with consideration given to the nature and mix of current and planned investments..." (citation adapted from Munnell et al. 2010). For most plans this expected yield turns out to be equal to $8 \%$ or close to $8 \%$ (Novy-Marx and Rauh 2008).

The Australian plan also employs the actuarial method and applies a discount rate of $8 \%$. The Australian PSS scheme for federal employees is partially funded, partially book-reserved, with assets at about $30 \%$ of liabilities.

The Norwegian SPK plan for federal employees is accounted for using the Norwegian accounting standard NRS 6 which is similar to the pension accounting standard required by US GAAP for corporate plan sponsors. The SPK plan is partially funded, partially book-reserved with assets at about $60 \%$ of liabilities. As of year-end 2009, the market-based discount rate was 5.70\%

The pension plan for federal employees of Sweden uses market-based discount rate that is net of future indexation. As of year-end 2008, this discount rate was $1.90 \%$.

The United Kingdom public sector pension plans are partly unfunded and partly funded in nature. Unfunded plans cover civil servants, national health sector and teachers. The 99 plans of the local communities all are based on funding. The reported evidence in the table therefore only concerns these local funded plans. The evidence is twofold. The first row for the UK plans is information for one specific plan, the West Yorkshire. The second row is an approximation of the size of assets and liabilities for all 99 plans. The reported value of liabilities is based on a discount rate of around 3\% (= $6 \%$ denominator discount rate minus $3 \%$ inflation rate). Cash flows are projected with an expected rate of inflation/indexation of 3\% (approached by taking the difference between the yield on long term gilts and the yield on inflation linked bonds). The denominator discount rate turns out to be equal to around 6\%, determined as the sum of the long term gilt return plus assumed outperformance of assets over the gilt return, being $2 \%$ for assets relating to preretirement service and $1 \%$ for postretirement. On average this corresponds with a denominator discount rate equal to around $6 \%$.

The French public service additional pension scheme (RAFP) has been created as a result of the French pension reform law of August 21, 2003, and is operative since January 1, 2005. The scheme manages the additional retirement benefit rights of French government and local authorities civil servants and the staff of French public hospitals, through a fully funded scheme.

With almost 4.6 million beneficiaries, 51,000 employers and contributions of more than 1.5 billion euros per annum, RAFP is one of the world's largest public pension funds in terms of members. The size of the plan assets and liabilities were relatively small at the end of 2008, at 6.1

\footnotetext{
${ }^{10}$ The reason for the use of the swap curve instead of the yield curve of Dutch government bonds as proxy for the riskfree rates interest is that the swap market is more developed (more trade terms and many more participants) and so much less sensible for incidental market disturbances.
} 
BEUR and 5.4 BEUR respectively, as the plan is quite young after four years of operations. The plan assets and liabilities are expected to grow rapidly. The discount rate is $1.80 \%$.

Table 4.1: Reported evidence by plans in consideration (end 2008)

\begin{tabular}{|c|c|c|c|c|c|c|}
\hline Country & Plan & Assets & Liabilities & $\begin{array}{l}\text { Funding } \\
\text { Residue }\end{array}$ & $\begin{array}{r}\text { Funding } \\
\text { Ratio }\end{array}$ & $\begin{array}{c}\text { Discount } \\
\text { Rate }\end{array}$ \\
\hline & & in eu & os end of & $\underline{008}$ & & \\
\hline \multirow[t]{2}{*}{ Canada } & Public Service (31 March 2008) & 70.0 & 66.8 & 3.2 & $104.9 \%$ & $6.00 \%$ \\
\hline & OTTPF (2008) & 62.1 & 68.6 & -6.5 & $90.5 \%$ & $4.00 \%$ \\
\hline France & Public Service Addi t ional Pension Scheme & 6.1 & 5.4 & 0.7 & $112.5 \%$ & $1.80 \%$ \\
\hline \multirow[t]{2}{*}{ Netherlands } & ABP (2008) & 175.6 & 195.7 & -20.1 & $89.8 \%$ & $3.57 \%$ \\
\hline & PfZW (2008) & 71.3 & 78.7 & -7.3 & $90.7 \%$ & $3.55 \%$ \\
\hline Sweden & federal (2008) & 20.0 & 19.0 & 0.9 & $104.8 \%$ & $1.90 \%$ \\
\hline Norway [1] & federal (2008) & 18.9 & 28.2 & -9.3 & $67.0 \%$ & $5.80 \%$ \\
\hline \multirow[t]{2}{*}{ UK [2] } & WestYorkshire & 4.4 & 5.5 & -1.1 & $79.6 \%$ & $6.00 \%$ \\
\hline & Approx. all local government plans & 317.8 & 542.1 & -224.2 & $58.6 \%$ & $6.00 \%$ \\
\hline US [3] & All state and local plans & 1374.3 & 2110.8 & -736.5 & $65.1 \%$ & $8.00 \%$ \\
\hline \multirow[t]{2}{*}{ Australia } & CSS Super (31 June 2008) & 3.0 & 32.0 & -29.0 & $9.3 \%$ & $7.54 \%$ \\
\hline & ESS Super (31 Dec 2008) & 8.5 & 13.8 & -5.3 & $61.5 \%$ & $8.00 \%$ \\
\hline
\end{tabular}

[1] Annual report states at value assets: "fictituos fund'

[2] UK has 99 local plans and approximation is based on the three biggest plans

[3] Data US derived from Novy-Marx and Rauh (2009)

\subsection{Funding positions for different methods of valuation}

The previous section has clarified that funded public sector plans use different methods and assumptions for valuing future pension benefit cash flows. Differences could include discount rates, mortality tables, actuarial methods and disclosure practices. Such differences stem from historical reasons and regulatory practices, but unfortunately, these differences in valuation and disclosure hinder a comparison of the funding positions of public sector pension plans on comparable terms. In order to make these liabilities truly comparable, they would need to be recalculated using the same methods and assumptions.

We do not attempt to fully recalculate the liabilities using the same methods and assumptions, but in order to make the liabilities at least somewhat more comparable, they have been approximately adjusted as if they were calculated using comparable discount rates across countries, using (i) marketbased discount rates based on the long-term nominal swap rates in each country and (ii) a fixed discount rate related to the expected return on assets held by the pension funds. Please note that we have made no adjustment for differences in other assumptions such as mortality tables, whether or not future salary increases are included in the liabilities and potential differences in asset valuation, so our revaluation can only be considered as a very rough approximation of a more "comparable" set of funding levels.

\subsubsection{Discounting methods}

There are different ways to arrive at a discount rate for pension fund liabilities. The choice of the discount rate can be related to the expected return on assets in portfolio. The discount rate can also be 
based on the characteristics of the pension liabilities. The former approach typically has been advocated by actuaries and plan sponsors, whereas the latter approach in general is supported by finance theory and financial economists (Bader \& Gold 2003, Gold \& Latter 2009). We make use of both approaches in comparing the funding positions of public sector pension funds.

\section{Liability-based discount rate}

Finance theory states that the appropriate discount rate should reflect the riskiness of the pension liabilities (Novy-Marx \& Rauh 2010). When it is highly likely that pension promises to public sector employees will be incurred, then the appropriate discount rate would be the risk-free interest rate which can be derived from government bonds or from the inter-bank market for interest-rate swap contracts. Pension funds in the Netherlands for example have to value their liabilities using this interbank swap curve. An advantage of using the swap curve above the government bond markets is that the inter-bank swap markets are well-developed and is free from credit risk pricing.

A main drawback of fair value accounting is that the volatility of interest markets results in a very volatile value of pension fund liabilities even though the underlying benefit cashflows may not change. An alternative for fair value approach might be the use of a fixed discount rate related to some long-term average of the rate of interest on long government bonds or related to some assumed value as a good proxy for the interest rate on government bonds. Such a rate should also be consistent with long-term trends in economic growth, which ultimately determines the government's capacity to finance pensions.

\section{Asset-based discount rate}

The asset-based discount rate approach typically relates the discount rate to the assumed rate of return on the assets held in the pension fund. The motivation may be found in the long-term orientation in funding pension promises. Pension funds invest for the long term so periods with belowaverage returns can be averaged out with periods with higher returns. Private sector pension funds are hindered in following this practice as their sponsors are exposed to market competition and related discontinuity risk. This justifies market-based accounting to inform the fund's stakeholders about the funding position instead of an asset-based approach. The government as sponsor of government pension funds however is by far less handicapped in following a long-term approach in funding because of its power to tax and its ability to survive the ups and downs of the business cycle and the stock market volatility. A fixed discount rate based on an assessment of long-term earning capacity of assets held, adds to intergenerational equity as yearly contributions are determined on an equal base. Such approach can also be justified if one considers that the benefit payouts are also volatile, as they depend on parameters such as wage growth, job turnover, and longevity whose future evolution is uncertain.

What would be an appropriate level for the fixed discount rate? One may fall back on historical performance as guidance for the expected future rates of return. Looking back over a long period justifies the use of a relatively high discount rate (around $8 \%$ or even more) but restricting the period implies much lower average returns ${ }^{11}$. The US state pension funds are allowed to use a rate of $8 \%$. We

\footnotetext{
${ }^{11}$ The US state pension funds earned over the period 1989-2009 on average 8.1\%, however over the period 1999-2009 just 3.9\% (Lav\&McNichol 2011). The Canadian Ontario Teachers pension fund reports over this period 1990-2009 an average return of 9.7\% and over the period 2000-2009 $6.2 \%$ (website). The Dutch pension fund for the government ABP earned an average return over the years 1993-2010 of 7.1\%, much lower than the North-America pension funds because of a more conservative asset mix (OECD 2009).
} 
base our calculation on a fixed discount rate of $6 \%$, simply assuming that pension funds hold a $50 \%$ equity and 50\% fixed income positions, yielding respectively $7.5 \%$ and $4.5 \%$.

\subsubsection{Funding positions}

The revaluation of the liabilities makes use of the following formula (compare Biggs 2010 and Novy-Marx\&Rauh 2008 who also employ this revaluation rule):

$$
\mathrm{L}_{\text {var iant }}=\mathrm{L}_{\text {reported }}\left(\frac{1+\mathrm{r}_{\text {reported }}}{1+\mathrm{r}_{\text {var iant }}}\right) \text { Duration }
$$

where $r_{\text {reported }}$ stands for the discount rate as reported by the plans and $r_{\text {variant }}$ reflects the discount rate of the alternative valuation method.

The term duration in the expression measures the money-weighted average maturity of the benefit cash flows. The duration also roughly corresponds to the elasticity of value of the liabilities with respect to the rate of interest $\mathrm{t}^{12}$. The term duration is sometimes also explained as the percentage increase or decrease in a plan's liabilities due to a 100 basis point decrease or increase in the discount rate.

The actual duration of the liabilities of a specific plan is determined by the composition of the terms of plan liabilities, however we assume for all plans that the duration of the liabilities is 15 years. Generally speaking this assumed duration of 15 years is a quite good approximation of the duration for most funded DB plans, but indeed a duration of 15 year is too high for a very mature fund and too low for a very young plan.

Table 4.2 displays four panels where each panel is subdivided into three different methods of valuation.

The four panels are:

- $\quad$ Panel A: Pension liabilities in billion Euros

- $\quad$ Panel B: Pension liabilities as \% GDP

- $\quad$ Panel C: Funding ratios

- $\quad$ Panel D: Pension fund residual as \% of GDP

${ }^{12}$ The change in the value of the liabilities $\Delta \mathrm{L}$ because of a change in the value or rate of interest $\Delta \mathrm{r}$ can be approximated with the following expression, with $\mathrm{D}$ as duration: $\Delta \mathrm{L} \approx-\mathrm{D} \Delta \mathrm{r}$

Mismatch risk is the standard deviation of the growth rate of the funding ratio. The number of $10 \%$ reflects the thumb-of-rule knowledge of ALM professionals that a pension fund with a mix of $50 \%$ bonds and 50\% equities, a duration of the liabilities of 15 years and a duration gap of 10 to 12 years has a mismatch risk of around $10 \%$. 
Each panel is subdivided to four different methods of valuation:

1. Reported:

Liabilities as reported by the individual schemes, based on local regulatory practice.

2. Liability-based discount rate: inter-bank swap rate curve

The "fair value" liabilities are our very rough approximation as to the liabilities of the individual schemes, determined using a market-based discount rate. This valuation method is inspired by the Netherlands ${ }^{13}$. As the market for government bonds in the Netherlands is quite limited in size and trading rates, the supervisor prescribes fair valuation has to be based on the nominal swap curve. We use the 30-years nominal swap rate as the market discount rate for nominal liabilities as the duration of a 30-years swap rate is about 15 years.

Table 4.3 informs on the 30-years nominal swap rates end 2008 for the different countries.

3 Liability-based discount rate equal to $4.5 \%$

This method bases the valuation on an assumed nominal interest rate on government. This rate is assumed to be $4.5 \%$, being the sum of $2.5 \%$ real interest rate and $2 \%$ expected inflation. This rate is also consistent with long-term GDP growth rates in OECD countries, which reflects the growth in the tax base of the government which is the financing source for public pensions.

4. Asset-based discount rate equal to $6 \%$

The valuing of the liabilities is based on an assumed discount rate of $6 \%$ as proxy for the assumed rate of return on assets. We base our calculation on a fixed discount rate of $6 \%$, simply assuming that pension funds hold a $50 \%$ equity and $50 \%$ fixed income positions, yielding respectively $7.5 \%$ and $4.5 \%$.

${ }^{13}$ One may ask why the Netherlands do not use real discount rates as they aim at full indexation of accrued nominal benefits. The actual granting of indexation depends on whether there is overfunding above the nominal value of pension liabilities. As indexation is uncertain and dependent on the funding position, Dutch pension funds therefore need not to account for the indexation ambition explicitly and can make use of nominal swap rates and not real rates. . 
Table 4.2: Funding position of funded public sector pension plans as reported by plan sponsors, using a market-based discount rate, using an assumed long-term government interest rate of $4.5 \%$ and using a an assumed rate of return on assets of $6 \%$

\begin{tabular}{|ll|rrrr|}
\hline Panel A & \multicolumn{5}{|c|}{ Liabilities in EUROS } \\
& & \multicolumn{4}{c}{} \\
\hline \hline Country & Plan & Reported & Swap & Rb 4.5\% & ER 6\% \\
\hline \hline Canada & Public Ser & 66.8 & 94.5 & 86.7 & 66.8 \\
& OTTPF & 68.6 & 73.0 & 57.8 & 51.5 \\
Netherland ABP & 195.7 & 195.7 & 153.6 & 138.2 \\
& PfZW & 78.7 & 84.8 & 62.2 & 55.4 \\
Sweden & federal & 19.0 & 16.4 & 13.7 & 10.5 \\
UK & WestYorks & 5.5 & 8.1 & 5.5 & 5.5 \\
& Approx. all & 542.1 & 795.9 & 393.6 & 542.1 \\
US & All plans & 2110.8 & 4444.3 & 2252.7 & 2793.9 \\
Australia & CSS Supe & 32.0 & 60.7 & 4.6 & 39.7 \\
& ESS Super & 13.8 & 27.9 & 13.9 & 18.2 \\
Norway & federal & 28.2 & 34.0 & 22.8 & 27.4 \\
France & Additional & 5.4 & 4.2 & 4.1 & 2.9 \\
\hline
\end{tabular}

\begin{tabular}{|ll|rrrr|}
\hline Panel C & \multicolumn{5}{|c|}{ Funding ratios } \\
& & & & \\
\hline \hline Country & Plan & Reported & Swap & Rb 4.5\% & ER 6\% \\
\hline \hline Canada & Public Se & $104.9 \%$ & $74.0 \%$ & $80.8 \%$ & $104.9 \%$ \\
& OTTPF & $90.5 \%$ & $85.1 \%$ & $107.5 \%$ & $120.5 \%$ \\
Netherland ABP & $89.8 \%$ & $89.8 \%$ & $114.3 \%$ & $127.1 \%$ \\
& PfZW & $90.7 \%$ & $84.1 \%$ & $114.7 \%$ & $128.8 \%$ \\
Sweden & federal & $104.8 \%$ & $121.8 \%$ & $145.9 \%$ & $189.8 \%$ \\
UK & WestYorks & $79.6 \%$ & $54.2 \%$ & $80.8 \%$ & $79.6 \%$ \\
US & Approx. all & $58.6 \%$ & $39.9 \%$ & $80.8 \%$ & $58.6 \%$ \\
Australia & All plans & $65.1 \%$ & $30.9 \%$ & $61.0 \%$ & $49.2 \%$ \\
& CSS Supe & $9.3 \%$ & $4.9 \%$ & $65.0 \%$ & $7.5 \%$ \\
Norway & ESS Super & $61.5 \%$ & $30.4 \%$ & $61.0 \%$ & $46.4 \%$ \\
France & federal & $67.0 \%$ & $55.6 \%$ & $83.1 \%$ & $68.9 \%$ \\
& Additional & $113.0 \%$ & $146.3 \%$ & $148.1 \%$ & $207.2 \%$ \\
\hline
\end{tabular}

\begin{tabular}{|ll|rrrr|}
\hline Panel B & \multicolumn{4}{|c|}{ Liabilities as \%GDP } \\
& & & & \\
\hline \hline Country & Plan & Reported & Swap & Rb 4.5\% & ER 6\% \\
\hline \hline Canada & Public Ser & $6.7 \%$ & $9.5 \%$ & $8.7 \%$ & $6.7 \%$ \\
& OTTPF & $16.4 \%$ & $17.5 \%$ & $13.9 \%$ & $12.4 \%$ \\
Netherland ABP & $32.1 \%$ & $32.1 \%$ & $25.2 \%$ & $22.6 \%$ \\
& PfZW & $12.9 \%$ & $13.9 \%$ & $10.2 \%$ & $9.1 \%$ \\
Sweden & federal & $5.6 \%$ & $4.8 \%$ & $4.0 \%$ & $3.1 \%$ \\
UK & WestYorks & $0.3 \%$ & $0.4 \%$ & $0.3 \%$ & $0.3 \%$ \\
US & Approx. all & $28.9 \%$ & $42.4 \%$ & $21.0 \%$ & $28.9 \%$ \\
Australia & All plans & $20.9 \%$ & $44.1 \%$ & $22.4 \%$ & $27.7 \%$ \\
Norway & ESS Supe & $4.4 \%$ & $8.4 \%$ & $0.6 \%$ & $5.5 \%$ \\
France & federal & $1.9 \%$ & $3.9 \%$ & $1.9 \%$ & $2.5 \%$ \\
& Additional & $8.8 \%$ & $10.6 \%$ & $7.1 \%$ & $8.5 \%$ \\
\end{tabular}

\begin{tabular}{|ll|rrrr|}
\hline Panel D & & \multicolumn{4}{|c|}{ (Residu) as \%GDP } \\
\hline \hline Country & Plan & Reported & Swap & Rb 4.5\% & ER 6\% \\
\hline \hline Canada & Public Ser & $0.3 \%$ & $-2.5 \%$ & $-1.7 \%$ & $0.3 \%$ \\
& OTTPF & $-1.6 \%$ & $-2.6 \%$ & $1.0 \%$ & $2.5 \%$ \\
Netherland ABP & $-3.3 \%$ & $-3.3 \%$ & $3.6 \%$ & $6.1 \%$ \\
& PfZW & $-1.2 \%$ & $-2.2 \%$ & $1.5 \%$ & $2.6 \%$ \\
Sweden & federal & $0.3 \%$ & $1.0 \%$ & $1.8 \%$ & $2.8 \%$ \\
UK & WestYorks & $-0.1 \%$ & $-0.2 \%$ & $-0.1 \%$ & $-0.1 \%$ \\
& Approx. all & $-11.9 \%$ & $-25.5 \%$ & $-4.0 \%$ & $-11.9 \%$ \\
US & All plans & $-7.3 \%$ & $-30.5 \%$ & $-8.7 \%$ & $-14.1 \%$ \\
Australia & CSS Supe & $-4.0 \%$ & $-8.0 \%$ & $-0.2 \%$ & $-5.1 \%$ \\
\multirow{2}{*}{ Norway } & ESS Super & $-0.7 \%$ & $-2.7 \%$ & $-0.8 \%$ & $-1.4 \%$ \\
France & federal & $-2.9 \%$ & $-4.7 \%$ & $-1.2 \%$ & $-2.7 \%$ \\
& Additional & $0.03 \%$ & $0.09 \%$ & $0.1 \%$ & $0.15 \%$ \\
\hline
\end{tabular}


Table 4.3: 30-year swap rates

\begin{tabular}{|c|c|}
\hline Country & 30yr swap rate end 2008 \\
\hline \hline & \\
Canada & $3.35 \%$ \\
Finland & $3.57 \%$ \\
Netherlands & $3.57 \%$ \\
France & $3.57 \%$ \\
Sweden & $2.91 \%$ \\
Norway & $4.49 \%$ \\
UK & $3.32 \%$ \\
US [1] & $2.77 \%$ \\
Australia & $3.05 \%$ \\
\end{tabular}

[1] Swap rate US reached low at end 2008.

Swap rate US end 2009 was $4.56 \%$ and end june $20103.71 \%$

Panel A of table 4.2 reports the absolute value of liabilities in euros which is strongly related to the size of the country.

Panel B expresses the liabilities as percentage of GDP. The highest values can be found in the Netherlands with fair value liabilities around 45\% of GDP (sum of ABP and PfZW), the US with $44 \%$ and the UK $42 \%$.

Panel $\mathrm{C}$ informs on the funding ratios for the three different valuation models ${ }^{14}$. For the valuation method based on an expected rate of return of $8 \%$, the plans in Canada, the Netherlands, Sweden show up high funding ratios far above $100 \%$. Even with this favorable discounting method, plans in the UK and the US are severely underfunded. The level of funding is much lower for the alternative, fair value valuation method. Most plans turn up in severe underfunding. The best funded plan is in Sweden with a funding ratio of $121 \%$, whereas Australia and US have funding ratios with indexed liabilities around $30 \%$.

Panel D finally expresses the pension fund residue (the difference between assets and liabilities) as percentage of GDP. These results can be interpreted as the implicit government debt comparable with the implicit debt position of unfunded plans. Underfunding implies that accrued pension rights are not matched in full by adequate funding so that future tax payers may have to step in by additional tax payments to fund the part of pension promises that are yet unfunded.

The panels $\mathrm{C}$ and $\mathrm{D}$ of table 4.2 may suggest that underfunding in public sector pension funds is common. This is the case irrespective of the method used to value the pension liabilities, although the underfunding situation is clearly aggravated when the fair value approach is used. However, it has to be recognized that these funding ratios are derived from values during or just after the financial crisis. It might be possible that public sector pension funds are financially sound and healthy in less extreme periods, for example for those funds in the Netherlands, Canada and Sweden.

\footnotetext{
${ }^{14}$ Funding ratio is defined as assets over liabilities: funding ratio $=$ assets/liabilities. Funding residue is the balance
} between assets and liabilities; funding residue = assets - liabilities. 


\section{Section 5. Public sector pension plans not backed by pension plan assets}

The liabilities of public sector plans not backed by pension plan assets (either pay-as-you-go or book reserve) can be perceived as a kind of implicit government debt (Holzmann et al. 2004). The costs of pension promises are not borne by the generation that has granted them but have to be paid by later generations of taxpayers when they lead to actual pension payments. This section provides an estimation of the size of this implicit debt position for the plans in consideration in this paper. It is important to note, however, that government sponsorship of these plans and the relative guarantee that this may imply compared to the private sector may also be considered an implicit asset.

\section{Pay-as-you-go plans}

Some public sector pension schemes are financed on a pay-as-you-go basis. For these plans, no provision is made in the plan sponsors financial statements for any liability and benefits that come due are payable out of the plan sponsor's general budget.

The implicit debt position in pay-as-you-go financed plans actually is equal to the present value of future benefits based on the pension rights acquired in the past service years of plan participants, so the debt position may be perceived as the Accrued Benefit Obligation (ABO) of an pay-as-you-go financed plan when this plan would be interpreted as a fictitious funded DB plan. In the following table, panel A, we have very roughly estimated the fictitious $A B O$ of the pay-as-you-go financed plans ${ }^{15}$. For reason of comparing with the funded and book-reserved plans, the value of liabilities is calculated on a fair value basis (swap rate) and using a fixed discount rate of $4.5 \%$.

\section{Book-Reserved Public Sector Pension Schemes ${ }^{16}$}

Some public sector pension schemes finance their obligations using the book-reserve method. This means that the plan sponsor holds a provision in their balance sheet for the liabilities of the plan, but there are no assets that have been set aside in a pension fund to cover these obligations. Rather, as benefits become due, payments are made out of the plan sponsors general budget. Of the plans that we examined, the UK schemes for civil servants, the NHS and teachers are financed via the book reserve method.

As was done for the plans with pension fund assets in the previous section, following are the liabilities of the book-reserved plans on the reported basis, the fair value basis (using a market discount rate), and using a fixed discount rate of $4.5 \%$ :

\footnotetext{
${ }^{15}$ This estimation has been done using the annual benefit payments of the plans in recent years as reported by the plans themselves. For an accurate determination of the ABO, we also need to have knowledge first of the future cash flows based on accrued rights from past years of service, and secondly knowledge of the actuarial principles (e.g. mortality tables, career parameters) and the current composition of the scheme members regarding age and gender as these aspects determine the present value factors needed to "translate" benefit cash flows into the Benefit Obligations. As we have no knowledge of future benefit cash flows nor of present value factors, we have to fall back on rules of thumb that can be derived from the practice of real-life public sector pension funds offering benefits of the same kind.
}

${ }^{16}$ The Australian PSS scheme is partially funded, partially book-reserved, with assets at about 30\% of liabilities. The Norwegian SPK plan is partially funded, partially book-reserved with assets at about $60 \%$ of liabilities. These partially funded schemes have been discussed in section 4 on funded public sector pension plans. 
Table 5.1 Liabilities in pay-as-you-go and book-reserved plans

\begin{tabular}{|c|c|c|c|c|c|c|c|c|}
\hline \multirow[t]{2}{*}{ Panel A } & \multirow[b]{2}{*}{ PAY-AS-YOU-GO PLANS } & \multirow{2}{*}{$\begin{array}{l}\text { Benefits } \\
2008\end{array}$} & \multirow{2}{*}{$\begin{array}{l}\text { Reported } \\
\text { value } \\
\text { liabilities }\end{array}$} & \multirow{2}{*}{$\begin{array}{l}\text { Discount } \\
\text { rate }\end{array}$} & \multicolumn{2}{|c|}{$\begin{array}{l}\text { Fair value } \\
\text { liabilities }\end{array}$} & \multicolumn{2}{|c|}{$\begin{array}{r}\text { Liabilities } \\
\text { fixed } 4.5 \%\end{array}$} \\
\hline & & & & & in BEUR & as $\%$ GDP & in BEUR & s \% GDP \\
\hline France & $\begin{array}{l}\text { Fonct.de l'Etat, de magistrats et des mil } \\
\text { Collectivités locales } \\
\text { Sum }\end{array}$ & $\begin{array}{l}45.5 \\
12.4 \\
57.9\end{array}$ & $\begin{array}{l}\text { n.a. } \\
\text { n.a. }\end{array}$ & $\begin{array}{l}\text { n.a. } \\
\text { n.a. }\end{array}$ & $\begin{array}{c}1456 \\
397 \\
1853\end{array}$ & $\begin{array}{l}72 \% \\
19 \% \\
91 \%\end{array}$ & $\begin{array}{l}777 \\
212 \\
989\end{array}$ & $\begin{array}{l}38 \% \\
19 \% \\
48 \%\end{array}$ \\
\hline Germany & $\begin{array}{l}\text { Civil Servants } \\
\text { Other } \\
\text { Sum }\end{array}$ & $\begin{array}{l}28.7 \\
18.3 \\
47.0\end{array}$ & $\begin{array}{l}\text { n.a. } \\
\text { n.a. }\end{array}$ & $\begin{array}{l}\text { n.a. } \\
\text { n.a. }\end{array}$ & $\begin{array}{r}918 \\
586 \\
1504\end{array}$ & $\begin{array}{l}35 \% \\
23 \% \\
58 \%\end{array}$ & $\begin{array}{l}490 \\
313 \\
803\end{array}$ & $\begin{array}{l}19 \% \\
12 \% \\
31 \%\end{array}$ \\
\hline Sweden & Local governments & n.a. & 31 & n.a. & 27 & $7 \%$ & & \\
\hline Finland & $\begin{array}{l}\text { Local (KuEL) and Federal (VaEL) (a) } \\
\text { (a) net of funded part }\end{array}$ & 6.2 & n.a. & n.a. & 148 & $77 \%$ & 79 & $41 \%$ \\
\hline
\end{tabular}

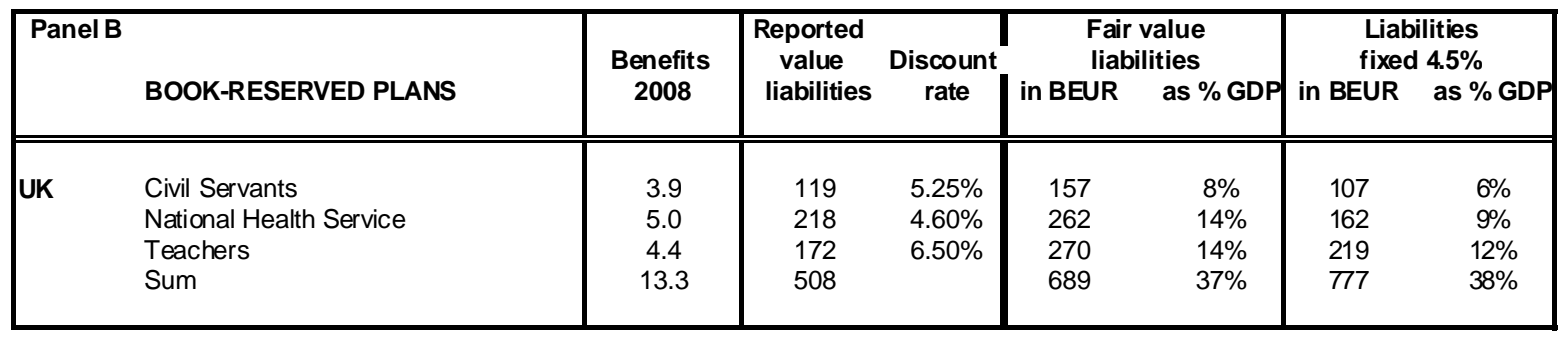




\section{Section 6. Net unfunded liabilities across countries}

Funded pension schemes, in principle, accumulate assets to cover the future payments of promises when those promises become payable. However, underfunding in funded plans could also be interpreted as implicit debt for future generations of tax payers. Underfunding implies that accrued pension rights are not matched in full by adequate funding now so future tax payers may have to step in to cover financial shortfalls. The residue position as percentage of GDP as reported in table 4.3, panel D can be interpreted as the implicit debt of future tax payers in funded plans. Table 4.5 in principle is the implicit debt position of the book-reserved scheme.

Figure 6.1 ties all information together of all the examined plans per country in order to get some perspective on the net unfunded liabilities on a fair value basis. Now we can compare the different examined plans, grouped by country, as to the fiscal burden for future tax payers in one dimension. In principle this fiscal burden, this implicit pension debt, can be replaced by explicit government debt, when the governments would turn to the capital market and borrow the money to back all unfunded pension promises made in the past up to now to public sector workers. However, to the extent that prefunding of government pension promises leads to investment in domestic government bonds, a circularity in government funding could be created.

The examined plans in France, Finland, the United Kingdom and Germany rank the highest in terms of net unfunded liability, with the French level reaching over 90\% of GDP and the Finnish one over 75\% of GDP. The net unfunded liabilities in Sweden, the Netherlands (ABP and PfZW together), Canada (only public servants) are low due to the relatively high funding levels in the examined funded plans. The examined plans in the United States (all state and local plans) and Norway fall in the middle.

The reported evidence reflects the actual size of the net unfunded liabilities best for France, Finland, United States, Norway, Sweden and the Netherlands as the examined plans in these countries cover more than $90 \%$ or even $100 \%$ of the active public sector employees (compare figure 3.1). For the United Kingdom, there is underreporting of the total net unfunded liabilities position as the considered plans cover less than $60 \%$ of the active workers in the public sector. This is also the case for Germany and even more so for Canada, as the reported Canadian plans represent about $10 \%$ of the total public sector workforce. 
Figure 6.1: Net unfunded liabilities of the examined public sector plans on fair value base as \% GDP (end of 2008)

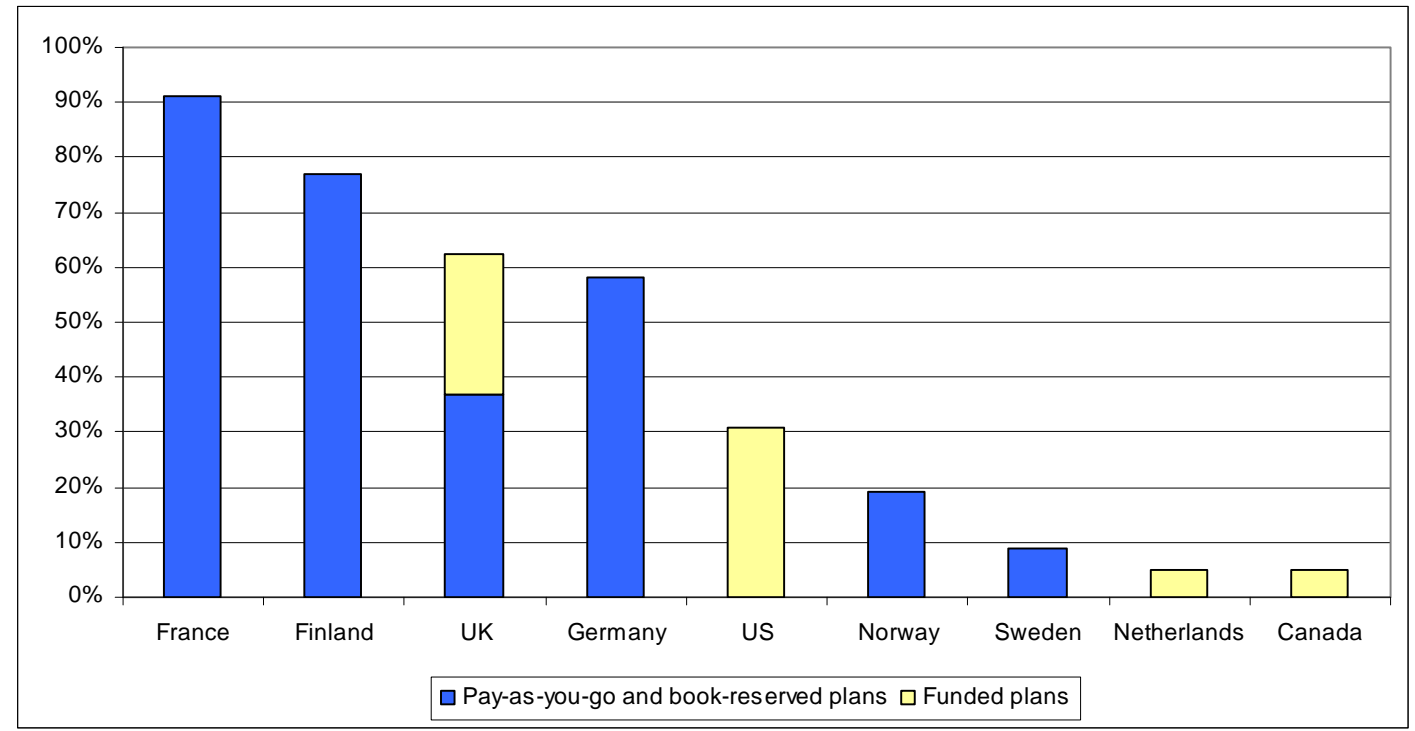

\section{Section 7 Public sector plans and creditworthiness of countries}

The credit crisis has made manifest that countries may default on meeting payment obligations of their explicit government debt. The reported net unfunded liabilities of public sector plans in Figure 6.1 can be interpreted as implicit government debt. The market would be expected to take also this implicit debt in consideration when evaluating the creditworthiness of a country. The market assessment of countries' creditworthiness can be derived from the market for credit default risk. Table 7.1 below reports for the countries under study the premium for the sovereign risk derived from the credit default swap (CDS) market, the explicit government debt position end 2009 for these countries, the net unfunded public sector liabilities (implicit pension debt) and the sum of the two debt positions. We are aware of the small number of countries in this sample, but nevertheless we have calculated the correlation between the CDSpremia and the debt positions.

The correlations between the premiums and, respectively, the implicit ${ }^{17}$, the explicit and the total debt positions are $0.58,0.76$ and 0.68 . So there is strong positive correlations between CDS premia and the implicit pension debt, but the correlation with the explicit debt is a bit higher, and so with the total debt. While the correlation between the implicit pension debt and the CDS premia may be driven by the explicit debt-CDS link, Table 7.1 also serves to highlight that some of the countries with the larger debt to GDP ratios also carry large unfunded pension liabilities for public sector workers.

17 The reported implicit debt positions in table 7.1 do not cover all public sector workers (compare figure 3.1). The correlations are calculated for a crude estimation of the total implicit debt by adjusting the reported implicit debt with an appropriate multiplier. 
Table 7.1: Credit swap rates and government debt

\begin{tabular}{|l|c|ccc|}
\hline & $\begin{array}{c}\text { CDS } \\
\text { (bpt) }\end{array}$ & $\begin{array}{c}\text { 2008 } \\
\text { Implicit debt }\end{array}$ & $\begin{array}{c}\text { 2009 } \\
\text { Explicit debt }\end{array}$ & Total debt \\
\hline \hline France & 123 & 91 & 61 & 152 \\
Finland & 44 & 77 & 38 & 115 \\
UK & 84 & 63 & 75 & 138 \\
Germany & 74 & 58 & 44 & 102 \\
US & 59 & 31 & 53 & 84 \\
Norway & 33 & 19 & 26 & 45 \\
Sweden & 44 & 8 & 38 & 46 \\
Netherlands & 74 & 5 & 50 & 55 \\
Canada*) & - & 5 & 36 & 41 \\
\hline & & & & \\
Correlation & & & & \\
with CDS & & 0.58 & 0.76 & 0.69 \\
\hline
\end{tabular}

*) No CDS premium available

Source: Datastream, authors' calculations

The impact of pension promises of government finances will also increase in the coming decades as demographic ageing continues, leading to increases in the ratio of retirees to workers. As shown in Figure 7.1, all the countries reviewed, with the exception of the United States, are expected to have old-age dependency ratios (the number of persons 65 years and older per one hundred persons 15 to 64 years) greater than 40 .

Such demographic trends will compound the fiscal pressures exerted not only by pension arrangements for government workers but more generally by unfunded, social security arrangements for private sector workers. As shown in Figure 7.2, public expenditure on pensions is expected to grow substantially in some of the countries considered in this report (between 2 and 4 percentage points of GDP), such as Finland, Germany, the Netherlands and Norway. However, of these four countries, only Finland and Germany also display a large implicit pension debt for public sector workers. 
Figure 7.1: Old age-dependency ratio and implicit pension debt

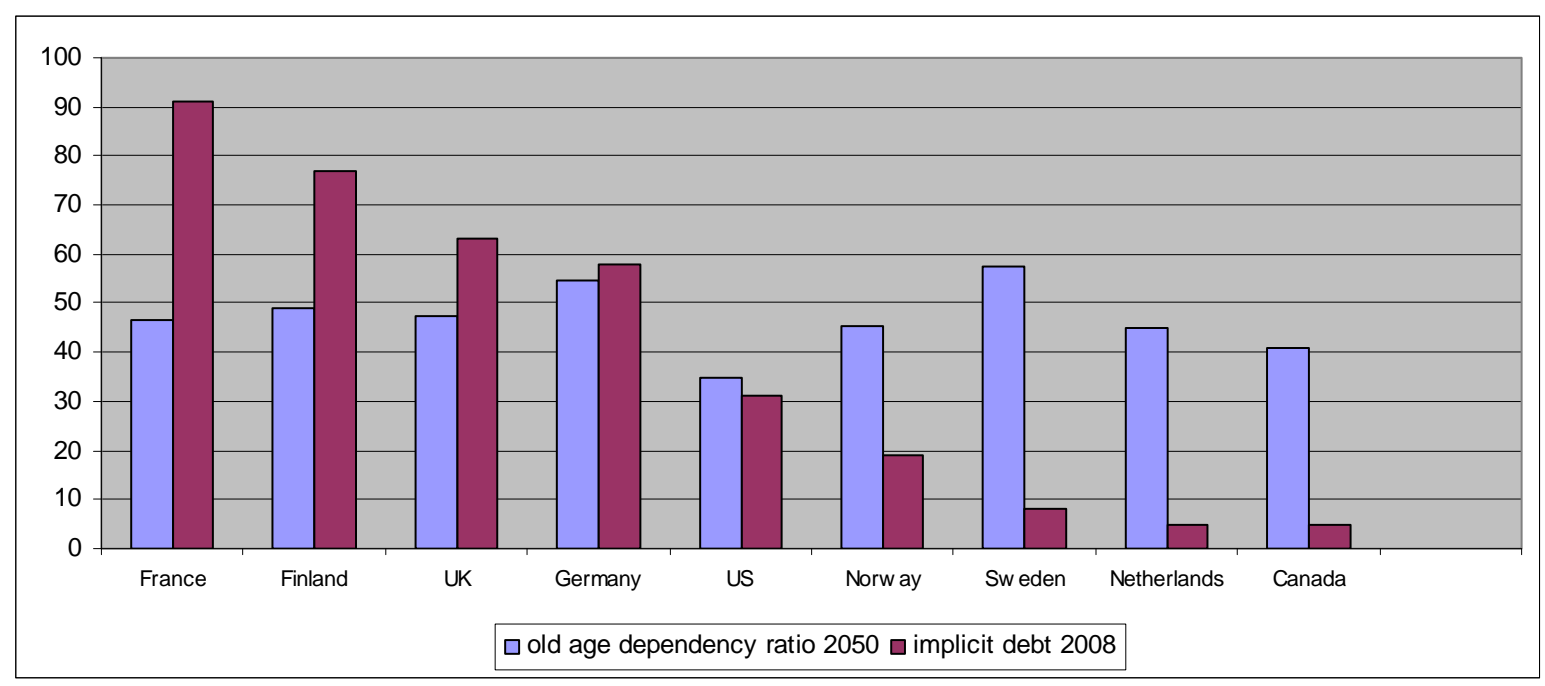

Figure 7.2: Increase in public expenditure on pensions as a \% of GDP, $2010-50$

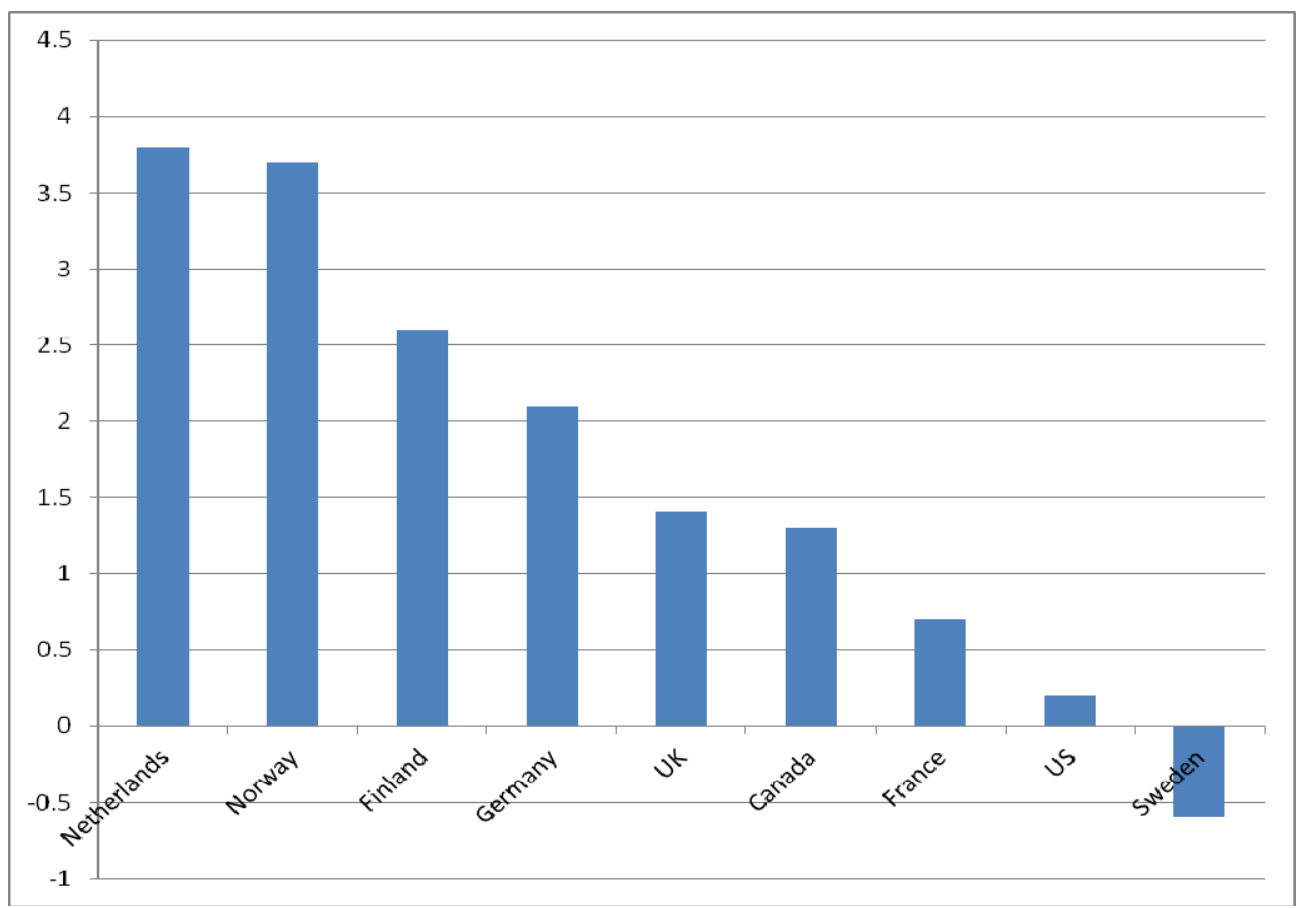

Source: OECD Pensions at a Glance 2011

\section{Section 8. Concluding Remarks}

Pension promises for government workers are a major policy challenge for four main reasons. Firstly, the state is usually the largest employer in the country and hence it usually faces large commitments to 
provide pensions for its employees. Secondly, these pension promises, often in the form of defined benefit plans, tend to be relatively generous, especially when compared to private sector arrangements. In some cases higher pension promises appear to have been made to make up for lower cash pay in the public sector relative to the private sector. Thirdly, these pension plans are in some countries underfunded or paid out directly from government revenues (the pay-as-you-go financing mechanism). Fourthly, there is as yet no internationally standardized method of reporting public sector pension liabilities, as there is for exchangelisted private sector companies in most countries. The valuation and disclosure of these promises is all too often less than transparent, which may be hiding potentially huge fiscal liabilities that are being passed on to future generations of workers.

The aim of this paper is to gather more evidence on public sector pension plans regarding the types of pension promises as well as a rough estimate of the future tax burden related to these pension promises for a select number of public pension schemes. Most OECD countries have special pension arrangements for public sector employees. On average $15 \%$ of the labour force in OECD countries is covered by government sector pension plans. The plans differ as to their financing base (funding or pay-as-you-go or some kind of book reserving), the nature of the promise (predominantly defined benefit plans, although some defined contribution plans also exist in some countries), and whether the plans are a complement to or a substitute for the country-wide public pension plans (the former is most common). We also find that government workers plans tend to be more generous than private sector plans, however Scandinavian plans offer similar benefits (and Swedish plans are actually less generous than the plans offered to a large portion of the private sector). The countries differ also considerably in the discounting method to value future pension liabilities. Methods range from a fixed discount rate based on the expected rate of return to fair value principles.

The paper did not attempt to explain these striking differences across countries. This asks for a broad socioeconomic analysis embracing country-specific historical, cultural, and institutional aspects. Instead, the research effort was directed at obtaining internationally comparable information on the funding level of on a selection of DB plans in different OECD countries.

A fair comparison between countries regarding the fiscal burden of their DB public sector pension plans is hindered by the country-specific use of valuation and reporting methods. In order to arrive at such a fair comparison, we have estimated for a number of plans the size of the net unfunded liabilities using a market discount rate ("fair value" approach) and using a common fixed discount rate, both as of end 2008.

This fiscal burden due to underfunding can also be interpreted as the implicit pension debt for a government as future generations of tax-payers may have to pay for these underfunded accrued pension promises. It should be noted, though, that the government sponsorship of these public sector DB plans could also be considered an implicit pension asset due to the relatively longer time horizon of the government plan sponsor and its potentially stronger level of creditworthiness as compared to plan sponsors in the private sector.

The limitations of the study should be considered. Not all pension plans for public sector workers were examined in each country. In France, Finland, Netherlands, Norway and Sweden, the plans analysed cover most (over 85\%) of public sector employees, so the plans can be considered representative of the public sector. On the other hand, for Canada, the implicit liabilities calculated only refer to plans covering $10 \%$ of the public sector, while the equivalent figure for Germany and the United Kingdom is about 50\%.

Furthermore, in estimating the liabilities on a fair value basis, we made a series of assumptions (such as their duration) as detailed actuarial information on the plans surveyed is not available. Irrespective of the valuation method used (actuarial or fair value), calculations of funding ratios, and the net unfunded liabilities are also subject to the potential criticism that they are based on a given set of assumptions that 
may not represent accurately the long-term financial challenge faced by governments in meeting their pension commitments on an ongoing basis. For instance, the use of market discount rates, as in the fair value approach, incorporates the erratic and not always rational behaviour of capital markets in the calculation of long-term pension commitments.

One key policy message from this study is that better disclosure and transparency is needed over the commitments made by governments to their public sector employees. While general social security systems are under increased scrutiny, information on public sector arrangements is often partial or not readily available. An international debate should also be opened on how to compare these commitments internationally, in order to assist the understanding of their fiscal impact. This paper has attempted to make a first attempt to providing such internationally comparable data. 


\section{REFERENCES}

Angelo, P., Brainard, K., Drazilov, M. and Zorn, P. (2010), Analysis of Joshua Rauh’s Paper “Are State Public Pensions Sustainable?”, available at http://nasra.org/resources/RauhResponse.pdf

Bader, L. N., and J. Gold (2003): Reinventing Pension Actuarial Science. Pension Forum 14(2): 1-13.

Biggs A.G. (2010); An Options Pricing Method for Calculating the Market Price of Public Sector Pension Liabilities, American Enterprise Institute \#164, February 2010.

Brackman, A, Grutz, J, Haug, T (2008); Civil servant pensions in National Accounts - Methodology and preliminary results (draft); Paper Prepared for the 30th General Conference of the International Association for Research in Income and Wealth; Portoroz, Slovenia, August 24-30, 2008.

British North-American Committee (2009): The Need for Transparency in Public Sector Pensions, A Comparative Study of Occupational Public Sector Pension Schemes in US, UK \& Canada, June 2009, BN49, British North-American Committee.

Cui J., F. de Jong and E.H.M Ponds (2011): Intergenerational risk sharing within funded pension schemes, in: Journal of Pension Economics and Finance, 10, 1-29.

D’Arcy, Dulebohn, J., and Oh, P. Optimal Funding of State Employees Pension Systems, Journal of Risk and Insurance, September 1999.

Disney R., C. Emmerson and G. Tetlow: What is a public sector pension worth?, The Economic Journal, 119 (November), 517-533.

Exley, C. J., S. J. B. Mehta, and A. D. Smith. 1997. The Financial Theory of Defined Benefit Pension Schemes. British Actuarial Journal 3: Part IV.

Gold J. and G. Latter (2009): The Case for Marking Public Plan Liabilities to Market, in: Mitchell O.S. and G.Anderson (eds.) The Future of Public Employee Retirement Systems, Oxford University Press.

Hoevenaars R. \& Ponds E.H.M. (2008): Valuation of intergenerational transfers in collective funded pension schemes, Insurance: Mathematics and Economics, vol. 42/2, pp. 578-593.

Holzmann R., Palacios R. and Zviniene A. (2004), Implicit Pension Debt: Issues, Measurement and Scope in International Perspective, working paper, The World Bank.

Kortleve N., \& Ponds E.H.M. (2006), Pension Deals and Value-based ALM, Chapter 10 in: KortleveN., Nijman T. \& Ponds E.H.M. (eds.): Fair Value and Pension Fund Management, Elsevier, Amsterdam, June 2006.

Kortleve N., Nijman T. \& Ponds E.H.M. (eds.): Fair Value and Pension Fund Management, Elsevier, Amsterdam, June 2006. 
Lav, I. and McNichol, E. (2001), "Misunderstandings regarding state debt, pensions, and retiree health costs create unnecessary alarm. Misconceptions Also Divert Attention from Needed Structural Reforms”, Centre on Budget and Policy Priorities, January 20, 2011

Maurer R., O.S. Mitchell, and R. Rogalla (2009): Reforming the German Civil Servant Pension Plan, in Mitchell O.S. and G. Anderson, The Future of Public Employee Retirement Systems, Oxford University Press.

Müller C., B. Raffelhüschen, and O. Weddige 2009, Pension obligations of government employer pension schemes and social security pension schemes estabilished in EU countries, by order of the European Central Bank, Final Report, Research Center for Generational Contracts, Freiburg.

Munnell A.H., R.W. Kopcke, J-P. Aubry \& L. Quinby (2010): Valuing Liabilities in State and Local Plans, Center for Retirement Research, Boston College, nr 11, June 2010.

Novy-Marx R. and J.D. Rauh (2008) The Intergenerational Transfer of Public Pension Promises, Research Paper no. 08-14 Chicago GSB.

Novy-Marx R. and J.D. Rauh (2009): The liabilities and risks of state-sponsored pension plans, The Journal of Economic Perspectives, fall 2009, vol. 23(4), 191-210.

OECD (2007), "Public Sector Pensions and the Challenge of an Ageing Public Service", OECD Working Papers on Public Governance, 2007/2, OECD Publishing. doi:10.1787/285530706017

OECD (2009): Pensions at a Glance 2009 Retirement-income systems in OECD countries, OECD Publising

Palacios R. and E. Whitehouse (2006): Civil-service pension schemes around the world, the World Bank, SP Discussion paper, no. 0602.

Peskin M. (2001): Asset/Liability Management in the Public Sector, in: Mitchell O.S. \& E.C. Hustead (eds.) Pensions in the Public Sector, University of Pennsylvania Press, Philadelphia.

Pinheiro V.C. (2004): Pension funds for government workers in OECD countries, mimeo, OECD.

Public Sector Pension Commission (2010): Reforming Public Sector Pensions, Solutions to a Growing Challenge, Report, July 2010, United Kingdom.

Pugh, C. and J. Yermo (2008), Funding Regulations and Risk Sharing, OECD Working Papers on Insurance and Private Pensions, No. 17, OECD Publishing. doi:10.1787/241841441002

Scott, I (2003); Organizations in the Public Sector in Hong Kong: Core Government, Quasi-Government and Private Bodies with Public Functions; Public Organization Review: A Global Journal 3: 247267 (2003); Kluwer Academic Publishers, the Netherlands.

Waring, B.M. (2009): A Pension Rosetta Stone: Reconciling Actuarial Science and Pension Accounting with Economic Values, working paper, Public Pension Finance Symposium May 2009. 